\title{
Ru Catalyst Facilitates Total Chemical Protein Synthesis to Investigate the Effect of Epigenetic Modifications Decorated on Linker Histone H1.2 and Heterochromatin Protein $1 \alpha(H P 1 \alpha)$
}

\author{
Naoki Kamo, Tomoya Kujirai, Hitoshi Kurumizaka, Hiroshi Murakami, Gosuke Hayashi,, Akimitsu Okamoto*
}

\begin{abstract}
For epigenetics research, preparing homogeneous proteins bearing site-specific posttranslational modifications (PTMs) is essential to understand the behavior of chromatin. Total chemical protein synthesis is a very powerful method to obtain target proteins with various modifications at site-specific positions. To produce large proteins efficiently, one-pot ligation of multiple peptide fragments was previously reported through repetitive deprotection of protecting groups for N-terminal Cys with palladium complexes. However, this method demanded more than a catalytic amount of metal complexes, and, in general, it had been challenging to achieve catalytic cycles of metal complexes especially for reactions on proteins. Here, we report an efficient and facile method of chemical protein synthesis using Ru catalyst. The use of 10-20 mol\% of Ru complexes enabled us to remove the protecting groups on peptides or proteins under peptide ligation conditions, and this complex showed more than 50-fold activity compared to the previous palladium complexes due to the great stability toward thiol moieties. By using this Ru catalyst, we accomplished total chemical synthesis of linker histone H1.2 (212 amino acids) and heterochromatin protein $1 \alpha$ (HP1 $\alpha$ ) (191 amino acids), which are important components of heterochromatin, through one-pot multiple peptide ligation. This method prompted the preparation of H1.2 and HP1 $\alpha$ bearing various patterns of PTMs. Moreover, we found that R53Cit at H1.2 reduced its binding affinity toward nucleosomes and four consecutive phosphorylations at N-terminus HP1 $\alpha$ controlled its binding ability against DNA. We envisage that homogeneously modified proteins prepared by our method would facilitate epigenetics research and be applied for the elucidation of various biological phenomena.
\end{abstract}

\section{INTRODUCTION}

In epigenetics research, it is critical to elucidate the functions of posttranslational modifications (PTMs) on proteins that are located in the cell nucleus to understand the regulating mechanism of transcription. ${ }^{1}$ Total chemical protein synthesis has prompted the preparation of target proteins bearing site-specific PTMs and functional molecules. ${ }^{2}$ For example, this technique was used to prepare modified core histone proteins (H2A, H2B, H3, and H4) to elucidate the properties of PTMs. ${ }^{3-6}$ To obtain chemically synthesized proteins, the target protein was divided into multiple peptide segments and each peptide segment was synthesized mainly by 9-fluorenylmethyloxycarbonyl solid-phase peptide synthesis (Fmoc-SPPS), ${ }^{7}$ but it was difficult to extend the peptide length beyond 50 amino acids. To join divided peptide fragments, native chemical ligation (NCL) is the most widely employed peptide ligation method. ${ }^{8}$ This reaction uses the chemoselectivity of $\mathrm{N}$-terminal cysteine (Cys) with a C-terminal thioester to form an amide bond between divided fragments. However, assembly of multiple peptide fragments to obtain medium-size proteins (e.g., $>20 \mathrm{kDa}$ ) required multiple reaction steps and purification, which led to low overall yields and timeconsuming works. To address this issue, one-pot multiple peptide ligation methods to eliminate the intermediate purification steps have been developed, but these methods were mainly exploited for assembling of three or four fragments to afford small proteins. ${ }^{9}$
Applications of metal complexes for chemical reactions on proteins, such as bioconjugation and decaging of protecting groups, have been well studied because metal complexes create unique reactivities. ${ }^{10,11}$ Recently, Brik and coworkers paved the way for the application of palladium (Pd) complexes for total chemical protein synthesis. ${ }^{3 d, 12}$ They employed various protecting groups that were labile with Pd complexes to protect N-terminal Cys and accomplished one-pot ligation of peptide segments. ${ }^{3 \mathrm{~d}, 12 \mathrm{~b}, 12 \mathrm{~d}}$ Our group employed allyloxycarbonyl (alloc) groups for the protection of N-terminal Cys, which were removed by using $\mathrm{Pd} / 3,3^{\prime}, 3^{\prime \prime}$-phosphanetriyltris(benzenesulfonic acid) trisodium salt (TPPTS) complexes. ${ }^{13}$ Furthermore, we used the triple function of 4-mercaptophenylacetic acid (MPAA): 1) A thiol additive to accelerate NCL reactions, 2) A scavenger for $\pi$-allyl Pd complexes; 3) A quencher of remaining Pd complexes after the alloc deprotection. This multifunctionality of MPAA enabled the first one-pot five-segment ligation to afford full-length histone H2AX. However, it was very challenging to achieve the deprotection of the alloc groups with only a catalytic amount of metal complexes under NCL conditions because of the presence of the excess amount of MPAA (MPAA: $100 \mathrm{mM}$ ), which possessed poisoning effects that degraded the activity of metal complexes. Generally, decaging or cross-coupling reactions on proteins required more than catalytic amounts of metal complexes, ${ }^{10 a}, 11 a$ probably because of the presence of functional groups on proteins such as thiol and imidazole groups, which coordinate to metal complexes. Moreover, 
some metal complexes (e.g., Pd/TPPTS complexes) are very unstable under aerobic conditions, and our previous one-pot ligation method required strict deoxygenated conditions. ${ }^{13}$ Furthermore, it was reported that some metal complexes caused the aggregation of proteins. ${ }^{14}$ Therefore, metal complexes that show catalytic activity even under NCL conditions, tolerated air atmosphere and minimized the possibility of the formation of protein aggregates, have been highly demanded to achieve efficient and facile total chemical protein synthesis.

To overcome these challenges, we focused on $\mathrm{Ru}$ complexes that can be used to catalytically deprotect alloc groups of small molecules under physiological conditions. ${ }^{15}$ We found that $\mathrm{Ru}$ complexes can show more than 50-fold activity compared with previous Pd/TPPTS complexes for the deprotection of the alloc groups on peptides under NCL conditions. A new one-pot peptide ligation method using Ru catalyst was applied for the total chemical synthesis of linker histone H1.2 (length: 212 amino acids, size: $22 \mathrm{kDa}$ ) and heterochromatin protein $1 \alpha$ (HP1 $\alpha$ ) (length: 191 amino acids, size: $22 \mathrm{kDa}$ ), which are essential components of heterochromatin. Especially, the use of the $\mathrm{Ru}$ catalyst prevented aggregation during the synthesis of HP1 $\alpha$, although we observed some aggregates using Pd complexes. H1.2s bearing PTMs, such as citrullination or phosphorylation, were synthesized to investigate the effects of these PTMs on the binding affinity toward nucleosomes. Furthermore, HP1 $\alpha$, bearing phosphorylation, acetylation, or ubiquitination, were chemically synthesized to examine the influence of those modifications on the binding toward DNA and the formation of complexes with DNA.

\section{RESULTS AND DISCUSSION}

Explorations of phosphine ligands for Pd. In previous research, we employed TPPTS, a water-soluble phosphine molecule, as a ligand for Pd to form Pd/TPPTS complexes for the deprotection of the alloc groups, and we found that 2.0 equiv. of $\mathrm{Pd} / \mathrm{TPPTS}$ complexes were required to remove the alloc groups under NCL conditions (peptide: 2 mM, MPAA: $100 \mathrm{mM}$, TCEP: $40 \mathrm{mM}$ in $\mathrm{Gn} \cdot \mathrm{HCl}(6 \mathrm{M})$ at $\mathrm{pH}$ 7.0). ${ }^{13}$ To explore more active Pd complexes, we screened phosphine ligands for $\mathrm{Pd}$ and evaluated the efficiency for the alloc removal. We selected bis(3-sulfonatophenyl)(2trifluoromethylphenyl)phosphine ( $\sigma$-Danphos), ${ }^{16}$ 3phosphanetriymono(benzenesulfonic acid) monosodium salt (TPPMS), and triphenylphosphan-3,3',3'tricarboxylate (TPPTC) ${ }^{17}$ as three-valent water-soluble phosphine ligands (Scheme 1). The electron density of $\mathrm{Pd}$ coordinated by $\sigma$-Danphos becomes lower compared to $\mathrm{Pd} / \mathrm{TPPTS}$ complex due to the presence of the substitution of the trifluoromethyl $\left(\mathrm{CF}_{3}\right)$ group. ${ }^{16}$ On the other hand, the electron density of Pd coordinated by TPPMS or TPPTC increases because of the reduction of the number of sulfonyl groups or the replacement of the sulfonyl groups with carbonyl groups, respectively. ${ }^{18}$ Furthermore, we tested 3-(di-tert-butylphosphonium)propane sulfonate (DBPPS), an alkyl phosphine that has much higher electron density than TPPTS. When we examined the deprotection yield of the alloc groups of peptide $\mathbf{1}$ using these Pdphosphine complexes, the Pd/TPPTS complex showed the best activity among them (Figure S1). When the electron density of Pd decreases, nucleophiles are known to attack $\pi$-allyl Pd complexes faster because of the increased electrophilicity of the $\pi$-allyl $\mathrm{Pd}$ complexes. In previous research, Pd/ $\sigma$-Danphos complexes showed higher activity for deprotection of the allyl groups under aqueous conditions compared to Pd/TPPTS complexes. ${ }^{19}$ However, probably because of the increased cone angle of $\sigma$-Danphos due to the presence of the $\mathrm{CF}_{3}$ group at its ortho-position and the decreased electron density of $\mathrm{Pd}$, the phosphine ligand was preferentially detached from Pd through ligand exchange with excess MPAA, which led to little catalytic activity of $\mathrm{Pd} / \sigma$-Danphos complexes under NCL conditions. Even when the electron density of Pd was increased by changing the phosphine ligands (e.g., Pd/TPPMS or $\mathrm{Pd} / \mathrm{TPPTC}$ complexes), we did not observe the quantitative removal of the alloc group. We considered that the deactivation of the $\mathrm{Pd}$ complexes by MPAA could proceed in preference to scavenging of $\pi$-allyl Pd complexes because the reaction rate of the attack of nucleophiles toward $\pi$ allyl Pd complexes could become slower due to the decreased electrophilicity of the $\pi$-allyl Pd complexes. Therefore, TPPTS had the most suitable phosphine ligands among those tested here, and we concluded that it would be difficult to remove the alloc groups under NCL conditions with only a catalytic amount of Pd complexes.

Scheme 1. Candidates for phosphine ligands for Pd.

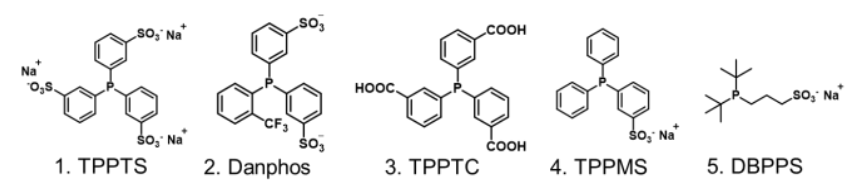

Exploration of Ru complexes bearing bidentate ligands. Under NCL conditions involving high concentration of MPAA, the metal complexes lost activity simultaneously with the deprotection of the alloc group because of the excess MPAA. Therefore, it was important to increase the stability of the metal complexes under NCL conditions to achieve catalytic reactions on peptides or proteins. To accomplish this goal, we focused on $\mathrm{Ru}$ complexes rather than Pd complexes. Electron-rich Pd (10 outer electrons) forms a strong bond with thiol moieties because of the $\pi$ back donation from Pd to the empty relatively low-energy d orbitals of the sulfur. ${ }^{20}$ On the other hand, electrondeficient $\mathrm{Ru}$ (8 outer electrons) favors ionic interactions to fill its d-band, and does not form a strong coordination bond with soft nucleophiles. Moreover, electron-rich Pd is more sensitive to electronic modification by sulfur poisoning, which causes significant changes in catalytic activity, than electron-poor $\mathrm{Ru}{ }^{21}$ Some researchers reported that $\mathrm{Ru}$ catalysts tolerated sulfur poisoning and catalyzed the allyl transfer to thiol moieties. ${ }^{22}$ In 1999, Mitsudo and coworkers investigated metal-catalyzed allyl transfer reactions using thiol moieties as nucleophiles. ${ }^{23}$ Although Pd or Ir complexes did not show any reactivities with the substrates, $\mathrm{Cp}{ }^{*} \mathrm{Ru}(\operatorname{cod}) \mathrm{Cl}\left(\mathrm{Ru}-1: \mathrm{Cp}^{*}=\eta^{5}\right.$ - 
Table 1. Deprotection of the alloc group of peptide 1 with Pd or Ru complexes under NCL conditions.
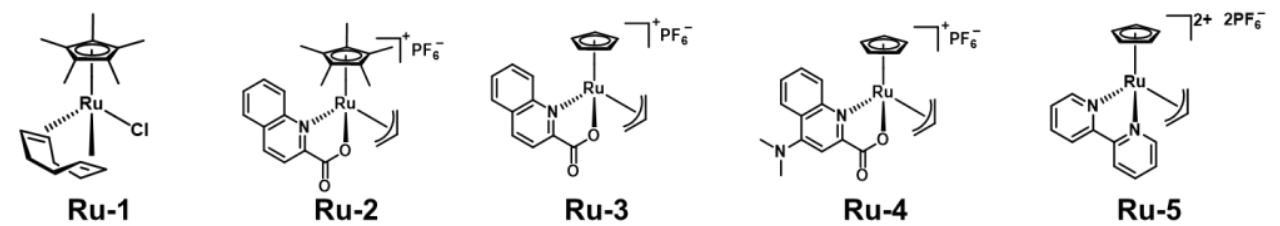

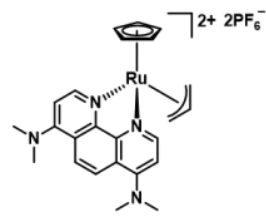

Ru-6

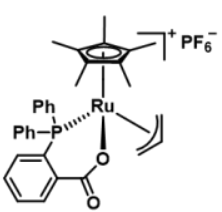

Ru-7

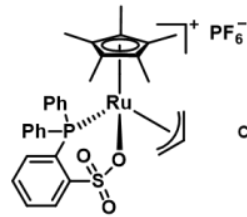

Ru-8

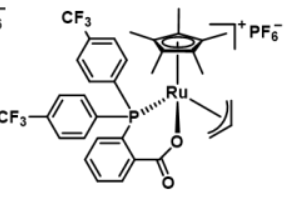

Ru-9

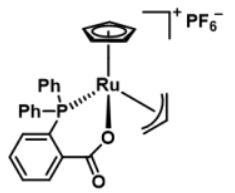

Ru-10

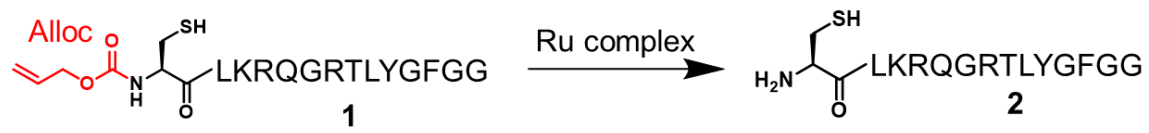

\begin{tabular}{|c|c|c|c|c|c|c|c|c|}
\hline \multirow[b]{2}{*}{ Entry } & \multirow[b]{2}{*}{ Metal complexes } & \multirow[b]{2}{*}{ Quantity (mol\%) } & \multirow[b]{2}{*}{ Additive } & \multicolumn{5}{|c|}{ Conversion yields [\%] ${ }^{\mathrm{a}}$} \\
\hline & & & & $10 \min$ & $30 \mathrm{~min}$ & $1 \mathrm{~h}$ & $2 \mathrm{~h}$ & $3 \mathrm{~h}$ \\
\hline 1 & Pd/TPPTS & 10 & - & 11 & 11 & 12 & 12 & 12 \\
\hline 2 & Ru-1 & 10 & - & 28 & 56 & 76 & 86 & 94 \\
\hline 3 & Ru-2 & 10 & - & 41 & 76 & 92 & $>95$ & - \\
\hline 4 & Ru-3 & 10 & - & $>95$ & - & - & - & - \\
\hline 5 & $\mathrm{Ru}-4$ & 10 & - & $>95$ & - & - & - & - \\
\hline 6 & $\mathbf{R u}-\mathbf{3}$ & 5 & - & $>95$ & - & - & - & - \\
\hline 7 & $\mathrm{Ru}-4$ & 5 & - & $>95$ & - & - & - & - \\
\hline 8 & Ru-4 & 5 & TCEP $(10 \mathrm{mM})$ & 8 & 9 & 10 & - & - \\
\hline 9 & Ru-5 & 5 & - & $<5$ & $<5$ & $<5$ & $<5$ & 6 \\
\hline 10 & Ru-6 & 5 & - & 7 & 10 & 14 & 17 & 17 \\
\hline 11 & $\mathbf{R u}-\mathbf{7}$ & 5 & - & 19 & 40 & 60 & 76 & 80 \\
\hline 12 & Ru-8 & 5 & - & $<5$ & 18 & 47 & 64 & 71 \\
\hline 13 & Ru-9 & 5 & - & 18 & 36 & 53 & 73 & 76 \\
\hline 14 & Ru-10 & 5 & - & 93 & $>95$ & - & - & - \\
\hline
\end{tabular}

aThe conversion yields were calculated from peak areas analyzed by HPLC (shown in Figure S2).

pentamethylcyclopentadienyl, $\quad \operatorname{cod}=\eta^{4-1,5-}$ cyclooctadiene) was not deactivated by thiol moieties, and catalyzed allyl transfer to the thiol groups. Kitamura and coworkers reported half-sandwich Ru complexes bearing N,O-bidentate ligand ([Cp*Ru(QA)allyl] $\mathrm{PF}_{6}(\mathbf{R u}-2$ : $\mathrm{QA}=2$ quinolinecarboxylate) and $[\mathrm{CpRu}(\mathrm{QA})$ allyl $] \mathrm{PF}_{6} \quad(\mathbf{R u}-3$ : $\mathrm{Cp}=\eta^{5}$-cyclopentadienyl)), which enabled efficient catalytic $S$-allylation of thiol moieties. ${ }^{24}$ Furthermore, Meggers and coworkers employed these complexes to remove the alloc groups of small molecules under physiological conditions containing glutathione (GSH) and air..$^{15}$ They incorporated a dimethylamino group into quinoline to increase the electron density of the $\mathrm{Ru}$ complexes. [CpRu(QA$\mathrm{NMe}_{2}$ )allyl]PF 6 (Ru-4: QA-NMe $=4$ - $(N, N$-dimethylamino)2-quinolinecarboxylate) showed more activity than Ru-3 under the same conditions and was applied for cellular experiments. However, these Ru complexes have not been used for peptides or proteins, which have higher molecular weight and possess functional groups at side chains, such as thiol and amine groups. Therefore, we decided to test whether these metal complexes could sustain the catalytic activity for the removal of the alloc group on a peptide under NCL conditions and air atmosphere. Ru-1 is commercially available, and Ru-2, Ru-3, and Ru-4 were synthesized according to previous reports (see the Supporting Information). After the preparation of each Ru complex, we tested the alloc deprotection on peptide 1 with $10 \mathrm{~mol} \%$ of metal complexes under NCL conditions in the presence of air (Table 1, Figure S2), and the conversion yields were calculated based on high-performance liquid chromatography (HPLC). In previous research, 2.0 equiv. of $\mathrm{Pd} / \mathrm{TPPTS}$ complex was required to attain quantitative removal of the alloc groups under NCL conditions. ${ }^{13}$ When the amount of the Pd complex was reduced to $10 \mathrm{~mol} \%$, the conversion yield reached to only $12 \%$ after $3 \mathrm{~h}$ (Table 1 , entry 1), indicating that TON of Pd/TPPTS complexes 
under NCL conditions was 1.2. In contrast, $\mathbf{R u - 1}$ and $\mathbf{R u - 2}$ sustained the catalytic activity even in the presence of a high concentration of MPAA (entries 2 and 3), and quantitative removal of the alloc groups was achieved after $2 \mathrm{~h}$ upon treatment with 10 mol\% Ru-2 (entry 3). Furthermore, only 5 mol\% of $\mathbf{R u - 3}$ or $\mathbf{R u}-\mathbf{4}$ rapidly catalyzed the alloc deprotection, and the reaction reached completion within 10 min (entries 6 and 7). We did not observe any side reactions, such as the transfer of the allyl groups to functional groups at side chains of peptide $\mathbf{1}$ (Figure S2), indicating that MPAA functioned as the main scavenger for $\pi$-allyl Ru complexes. The slow reaction rate of $\mathbf{R u}-\mathbf{2}$ compared to $\mathbf{R u}-\mathbf{3}$ could be explained by the sterically hindered $\mathrm{Cp}^{*}$ disturbing nucleophilic attack of MPAA toward $\pi$-allyl $\mathrm{Ru}$ complex, which was already reported. ${ }^{15} \mathrm{We}$ should note that the activity of the Ru complexes diminished in the presence of TCEP (entry 8), suggesting that trivalent phosphine greatly reduces the activity of Ru complexes. We decided to screen other $\mathrm{Ru}$ complexes for the alloc deprotection under NCL conditions. First we assessed the effect of replacing the N,O-ligand with an N,N-ligand, and synthesized $\left[\mathrm{Cp}\left(\eta^{2}\right.\right.$-bipy $)\left(\eta^{3}\right.$-allyl $\left.) \mathrm{Ru}^{\mathrm{IV}}\right]\left[\mathrm{PF}_{6}\right]_{2} \quad(\mathbf{R u}-\mathbf{5}$ : bipy=bipyridine $)$ and $\left[\mathrm{Cp}\left(\eta^{2}\right.\right.$-phen-NMe 2$)\left(\eta^{3}\right.$-allyl $) \mathrm{Ru}$ $\left.{ }^{\mathrm{IV}}{ } \mathrm{PF}_{6}\right]_{2}$ (Ru-6: phen=phenanthroline). ${ }^{25}$ However, the catalytic activities of Ru-5 and Ru-6 were much lower than those of Ru-3 or Ru-4 (entries 9 and 10) probably because of the rigid structures, which inhibited the oxidative addition.

Previous research showed that the rate-determining step of the alloc removal using $\mathbf{R u - 3}$ or $\mathbf{R u}-\mathbf{4}$ was the oxidative addition of the allyl groups toward $\mathrm{Ru}$ when strong nucleophiles, such as thiol moieties, were employed. ${ }^{15}$ To accelerate the uncaging of the alloc groups and further improve the stability under NCL conditions, we focused on $\mathrm{P}, \mathrm{O}$-bidentate ligands to replace $\mathrm{N}, \mathrm{O}$-ligands and increase the electron density of $\mathrm{Ru}$ complexes. Bruneau and coworkers reported $\mathrm{Ru}$ complexes coordinated by $O$ diphenylphosphino benzoate (o-DPPBz) or diphenylphosphinobenzene sulfonate (o-DPPBS), which catalyzed regioselective $\mathrm{C}$ - and $O$-allylation reaction. ${ }^{26} \mathrm{Howev}$ er, these $\mathrm{Ru}$ complexes bearing $\mathrm{P}, \mathrm{O}$-ligand had not been employed for the allyl transfer to thiol moieties. We synthesized previously reported $\left[\mathrm{Cp}^{*} \mathrm{Ru}\left(\kappa^{2}-o-\mathrm{DPPBz}\right)\right.$ allyl] $\mathrm{PF}_{6}$ (Ru-7) and $\left[\mathrm{Cp}^{*} \mathrm{Ru}\left(\kappa^{2}-o\right.\right.$-DPPBS)allyl]PF 6 (Ru-8). ${ }^{26}$ There was no significant difference between Ru-7 and Ru-8 (entries 11 and 12) for the alloc deprotection of peptide $\mathbf{1}$ under NCL conditions. To reduce the electron density of the phosphine ligand and enhance the nucleophilic attack of MPAA toward $\mathrm{Ru}$ complexes, we synthesized $\mathrm{Ru}$ complexes coordinated by $o$-DPPBz bearing $\mathrm{CF}_{3}$ groups (Ru-9), but no improvement of these Ru complexes over $\mathbf{R u - 8}$ was observed (entry 13). Considering the effective deprotection of the alloc group using Ru-3 compared to Ru-2 (entries 3 and 4), we synthesized [CpRu( 1 2-o-DPPBz)allyl] $\mathrm{PF}_{6}$ (Ru-10) for the first time, which was coordinated by $\mathrm{Cp}$. The deprotection efficiency was dramatically improved using Ru-10, and the reaction reached completion within 30 min (entry 14), indicating that Ru-10 showed the highest catalytic activity among Ru complexes coordinated by P,O-bidentate ligands.
Calculation of TON and investigation of differences between Ru complexes. We examined TON and turnover frequency (TOF) of $\mathbf{R u - 3 , ~ R u - 4 , ~ a n d ~} \mathbf{R u - 1 0 , ~ w h i c h ~ r e m o v e d ~}$ the alloc groups quantitatively with $5 \mathrm{~mol} \%$ catalysts. We reduced the amount of each $\mathrm{Ru}$ complex to $1 \mathrm{~mol} \%$ and tested the removal of the alloc group of peptide $\mathbf{1}$ under NCL conditions (Figure 1, Figure S3). Ru-3 (TOF: 19 min $^{-1}$ ) and Ru-4 (TOF: $20 \mathrm{~min}^{-1}$ ) showed similar TOF value, but the TON of Ru-4 (TON: 70) was slightly higher compared to Ru-3 (TON: 56), because of the presence of the $\mathrm{NMe}_{2}$ group in Ru-4, which increased the electron density of $\mathrm{Ru}$ and its stability against excess MPAA.

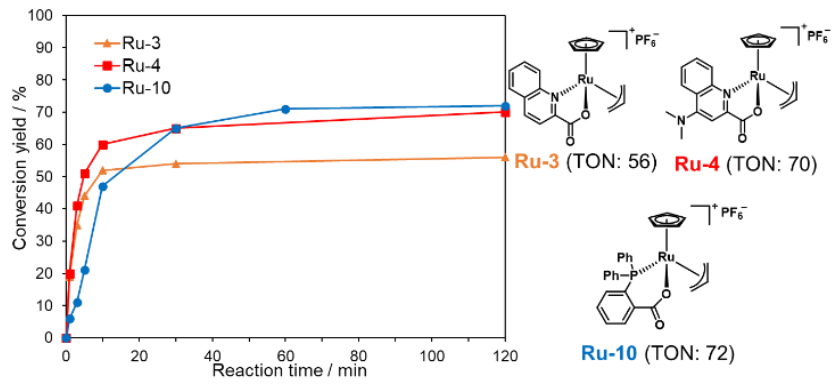

Figure 1. Investigation of TON and TOF. (A) Calculation of TON and TOF of 1 mol\% Ru-3, Ru-4, or Ru-10 for the deprotection of the Alloc group of peptide $1(2 \mathrm{mM})$ in NCL buffer [Gn·HCl (6 M), $\mathrm{NaH}_{2} \mathrm{PO}_{4}(200 \mathrm{mM}), \mathrm{MPAA}(100 \mathrm{mM})$ at $\left.\mathrm{pH} 7.0\right]$.

The reaction rate using $\mathbf{R u - 1 0}$ (TOF: $6 \mathrm{~min}^{-1}$ ) as a catalyst was slower than $\mathbf{R u - 3}$ or $\mathbf{R u - 4}$ due to the lower electrophilicity of $\pi$-allyl Ru complexes, but Ru-10 sustained its catalytic activity for a longer time because of its stability, and showed similar catalytic activity (TON: 72) to that of Ru-4 and higher than that of Ru-3. The different electrophilicities of Ru catalysts were well consistent with calculations based on density functional theory (DFT). The lowest unoccupied molecular orbital (LUMO) level of $o$-DPPBz was more than $0.5 \mathrm{eV}$ higher than $\mathrm{QA}$ and $\mathrm{QA}-\mathrm{NMe}_{2}(-1.44$ $\mathrm{eV}$ vs. $-2.15 \mathrm{eV}$ vs. $-1.94 \mathrm{eV}$ ) (Figure S4). This higher $\pi$ accepting ability of QA or QA-NMe 2 led to the higher electrophilicity of $\mathbf{R u - 3}$ or $\mathbf{R u - 4}$ and the attack of MPAA toward $\pi$-allyl $\mathrm{Ru}$ complexes became faster than $\mathbf{R u - 1 0}$. To summarize, compared to the activity of Pd/TPPTS complexes (TON: 1.2), Ru-4 and Ru-10 showed more than 50fold activity, and catalytically removed the alloc groups of peptides under aqueous conditions and even in the presence of 5,000 equiv. of MPAA, which normally poisoned the metal catalysts.

To further explore the difference between Ru-4 and Ru-10, we added these Ru complexes to a solution containing peptide $\mathbf{1}$ in the absence of MPAA, a scavenger for $\pi$ allyl $\mathrm{Ru}$ complexes (Figure S5). When $10 \mathrm{~mol} \%$ of Ru-4 was tested, peptide $\mathbf{1}$ was completely consumed within 30 min, and single or double allyl transfer to functional groups of peptides was observed (Figure S5). Based on MS/MS analysis of each HPLC peak (Figure S6), it was found that the allyl groups were transferred to amine groups or thiol groups of N-terminal Cys, not to other amino acids, such as Lys, Tyr, or Thr. When $10 \mathrm{~mol} \%$ of Ru-10 was examined, the starting material remained for over $1 \mathrm{~h}$ 
reaction, and the allyl transfer to peptide $\mathbf{1}$ barely occurred (Figure S5). These results indicated that $\mathbf{R u}-\mathbf{4}$ was more reactive with nucleophiles than $\mathbf{R u - 1 0}$ because of its more electrophilic $\pi$-allyl Ru complex, which presented the possibility of side reactions, such as allyl transfer to the functional groups of peptides via $\mathbf{R u}-\mathbf{4}$. However, in the presence of excess MPAA ( $\mathrm{p} K_{a}$ 6.6), ${ }^{27}$ this strong nucleophile attacked $\pi$-allyl $\mathrm{Ru}$ complex before peptides and suppressed the undesired reactions as seen by comparing HPLC data shown in Figures S2 and S5.

Inactivation of Ru complexes by MPAA. To achieve one-pot multiple peptide ligation, deactivations of metal complexes before the following NCL were critical steps. ${ }^{13}$ Therefore, we decided to investigate the deactivation of Ru-4 or Ru-10 under NCL conditions (Figure S7). Metal complex solutions containing $100 \mathrm{mM}$ MPAA at neutral $\mathrm{pH}$ were rotated for a certain time $(3,10$, or $30 \mathrm{~min})$, and powdered peptide 1 was added, then the removal of the alloc groups with each metal complex was analyzed by HPLC (Table 2). $200 \mathrm{~mol} \%$ of Pd/TPPTS complex was rapidly deactivated by MPAA and lost activity within $10 \mathrm{~min}$ (entry 1). In contrast, 10 mol\% of Ru-4 and Ru-10 against peptide 1 showed stability under NCL conditions (entries 2 and 3), and Ru-10 was more stable than $\mathbf{R u}-\mathbf{4}$ because of the higher electron density of Ru. We concluded that the greater stability of these Ru complexes over Pd complexes contributed to the catalytic activity for the removal of the alloc groups of peptides.

Table 2. Inactivation of metal complexes with MPAA.

\begin{tabular}{cccccc}
\hline & & \multicolumn{3}{c}{ Conversion yields [\%] } \\
\cline { 3 - 6 } Entry & Metal complexes & $(\mathrm{mol} \%)$ & $3 \mathrm{~min}$ & $10 \mathrm{~min}$ & $30 \mathrm{~min}$ \\
\hline 1 & Pd/TPPTS & 200 & 69 & $<5$ & - \\
2 & Ru-4 & 10 & $>95$ & 18 & $<5$ \\
3 & Ru-10 & 10 & $>95$ & $>95$ & 20
\end{tabular}

aThe conversion yields were calculated from peak areas analyzed by HPLC (shown in Figure S7).

The inactivation mechanism of Ru complexes coordinated by bidentate ligands was revealed by NMR and MALDITOF mass analysis. A premixture of MPAA and DIEA was added to the solution of Ru-3 in acetone- $\mathrm{d}_{6}$, and the whole mixture was stirred for $1 \mathrm{~h}$ at room temperature. We observed some precipitates in the solution, and the supernatant and the precipitates were separated. When the supernatant was analyzed by ${ }^{1} \mathrm{H}$ NMR, free QA detached from $\mathrm{Ru}$ was observed (Figure S8). The precipitates were then dissolved in a mixture of $\mathrm{CD}_{3} \mathrm{CN}$ and $\mathrm{D}_{2} \mathrm{O}$. The NMR spectrum of the precipitates showed peaks derived from MPAA and $\mathrm{Cp}$, suggesting that these were derived from Ru complexes (Figure S9). After the measurement of molecular weight by MALDI-TOF mass analysis, we identified the precipitates as a binuclear Ru complex coordinated by MPAA (Scheme 2, Figure S9). ${ }^{28}$ Therefore, the deprotonated MPAA caused the ligand exchange with Ru-3 and detached the QA, an original ligand, from Ru to form the binuclear Ru complex.

To summarize, the alloc deprotection of peptides by the $\mathrm{Ru}$ catalysts under NCL conditions proceeded very fast, and the reaction reached completion within $10 \mathrm{~min}$. Simultaneously, the $\mathrm{Ru}$ catalyst slowly lost catalytic activity through ligand exchange with MPAA to form a binuclear complex, enabling the following NCL (Scheme 2). Newly synthesized Ru-10 coordinated by P,O-ligands showed the highest catalytic activity and the greatest stability under NCL conditions among tested Ru complexes. However, considering the facile deactivation by MPAA, we decided to employ Ru-4 to attain total chemical synthesis of proteins through one-pot multiple peptide ligation.

Scheme 2. Simultaneous catalytic alloc deprotection and deactivation of Ru-4.

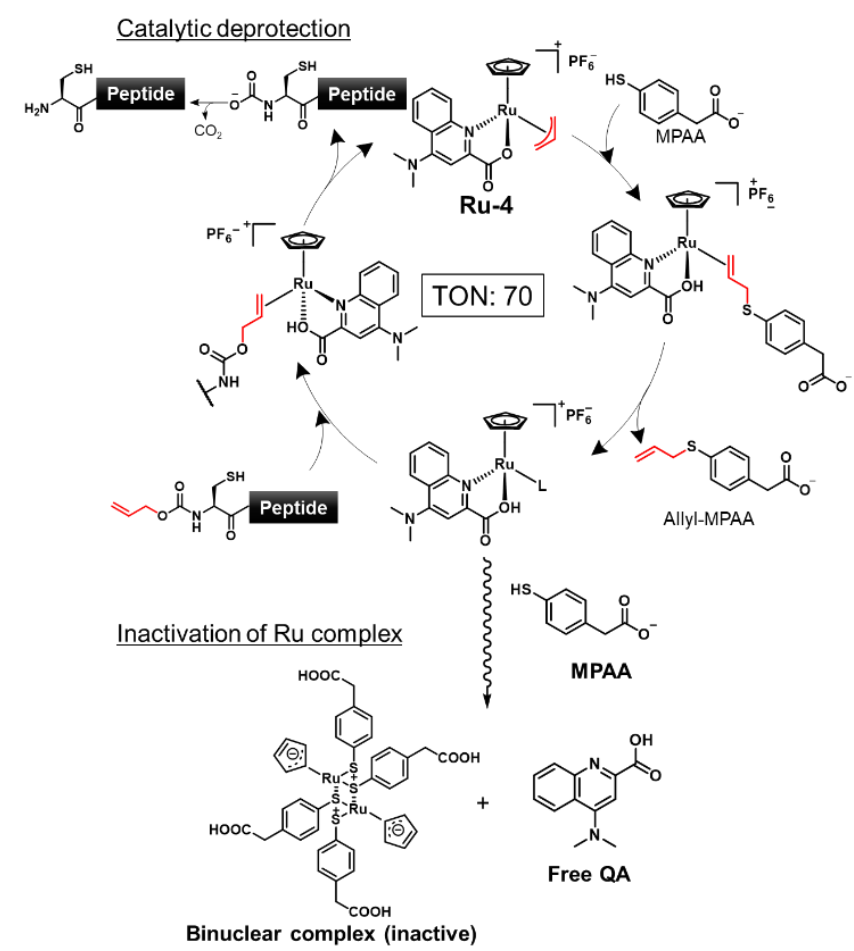

Chemical synthesis of histone H1.2. To demonstrate the utility of Ru-4 catalyst for chemical protein synthesis, we selected linker histone $\mathrm{H} 1.2$ as a target protein, which interacts with nucleosomes to form chromatosomes and contributes to the formation of a higher-order chromatin

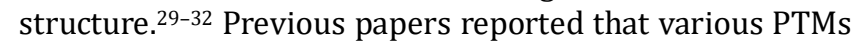
can be decorated on H1.2, such as acetylation, phosphorylation, and citrullination, and some of these modifications play roles in chromatin decondensation, which may promote reprograming of cells. ${ }^{33}$ However, it had been difficult to achieve the chemical synthesis of H1.2 compared to core histone proteins ( $<140$ amino acids), because of its large size (212 amino acids). Therefore, we aimed to establish a synthetic method to access H1.2 through one-pot multiple peptide ligation using $\mathbf{R u}-\mathbf{4} .^{34}$

As shown in Figure 2A, Cys mutations for NCL reactions were incorporated at Ala sites and divided into five peptide segments of $\mathrm{H} 1.2$ (peptides $\mathbf{3}, \mathbf{4}, \mathbf{6}, \mathbf{8}$, and $\mathbf{1 0}$ ), which were synthesized by Fmoc-SPPS (Figure S10). The Nterminal Cys of peptides $\mathbf{4}, \mathbf{6}$, and $\mathbf{8}$ were protected by the alloc groups, and the one-pot five-segment ligation using Ru-4 was performed. All the NCL reactions and the removal of alloc groups were conducted in NCL buffer $(6.0 \mathrm{M}$ guanidinium chloride, $200 \mathrm{mM} \mathrm{NaH} 2 \mathrm{PO}_{4}, 100 \mathrm{mM}$ MPAA) at $37^{\circ} \mathrm{C}$. 


\section{(A)}
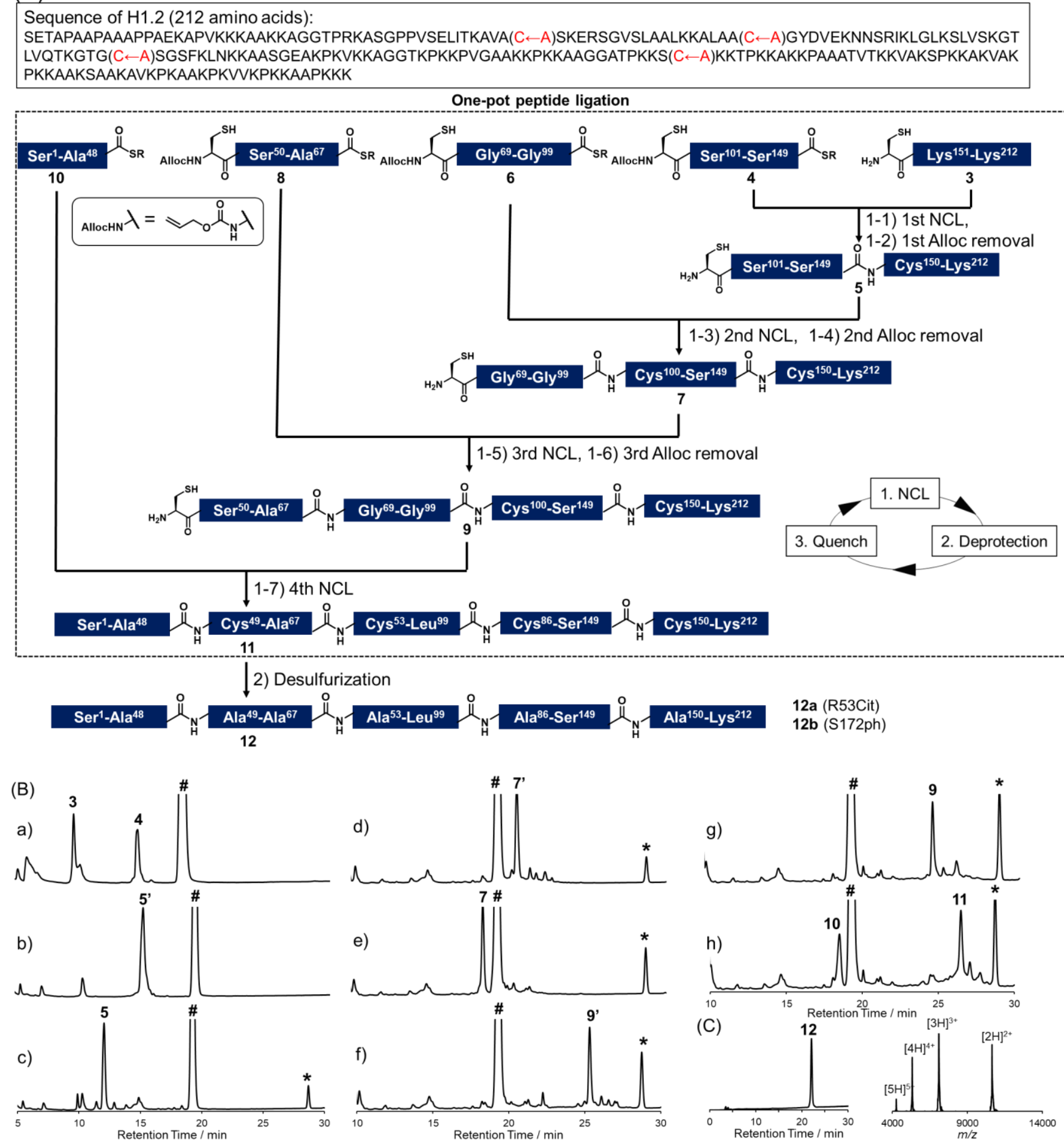

Figure 2. Chemical synthesis of linker histone H1.2 using the Ru catalyst. (A) Synthetic strategy. 1) NCL condition: peptides (2 mM), MPAA (100 mM) in denaturing buffer at pH 7.0, $37^{\circ} \mathrm{C}$. Removal condition: Ru-4 (20 mol\%), $37^{\circ} \mathrm{C}, 20 \mathrm{~min}$. 2) Peptide (0.8 mM), TCEP (300 mM), GSH (150 mM), VA-044 $(20 \mathrm{mM})$ in denaturing buffer at pH 7.0. (B) Reaction tracking of the one-pot ligation with catalytic amount of Ru-4 (20 mol\%) for the alloc deprotection by analytical HPLC (gradient: 10-46\% for $30 \mathrm{~min}$ ) at $220 \mathrm{~nm}$. Compounds 5', 7', and 9' are the alloc-protected peptides 5, 7, and 9, respectively. \# = MPAA. * = Allyl-MPAA. a) 1st NCL $(t=2 \mathrm{~min})$. b) 1st NCL ( $t=2 \mathrm{~h}$ ). c) 1 st deprotection. d) 2nd NCL ( $t=2 \mathrm{~h})$. e) 2 nd deprotection. f) 3rd NCL ( $t=2 \mathrm{~h})$. g) 3rd deprotection. h) 4 th NCL $(t=2 \mathrm{~h}$ ). (C) HPLC profile (left, gradient 20-50\% for 30min) and MALDI-TOF mass spectrum (right) of purified peptide 12. Calculated mass of $12[\mathrm{M}+2 \mathrm{H}]^{2+}:$ 10638.8; Mass Found $[\mathrm{M}+2 \mathrm{H}]^{2+}: 10639.4$.

Peptides 3 and 4 (1.1 equiv. relative to peptide 3 ) were dissolved in NCL buffer, and the NCL reaction reached completion within $2 \mathrm{~h}$ to afford peptide 5 (Figure 2B). Ru-
4 ( 0.2 equiv.) was added to the reaction solution, and the mixture was stirred for $30 \mathrm{~min}$ to remove the alloc group and deactivate $\mathbf{R u - 4}$. After completion, a small amount of 
TCEP solution was added to reduce disulfide bonds and be consumed completely before the next the alloc removal with Ru-4. Powdered peptide 6 was then added to initiate the second NCL reaction. These operations were repeated for the second deprotection and the third NCL and deprotection (Figure 2B). Finally, powdered peptide $\mathbf{1 0}$ was added to initiate the fourth NCL reaction. HPLC analysis after $2 \mathrm{~h}$ showed a major peak corresponding to the desired ligated peptide $\mathbf{1 0}$ (Figure 2B). The reaction product was purified by HPLC, and the desired peptide $\mathbf{1 0}$ was obtained in $23 \%$ yield from 3 . The purity of peptide $\mathbf{1 0}$ was confirmed by HPLC and MALDI-TOF MS analysis (Figure S11). Compared to the previous one-pot ligation method with Pd/TPPTS complex, ${ }^{13}$ the total amount of metal complexes was reduced to 0.6 equiv. (Pd: more than 6.0 equiv.), and strict deoxygenated conditions established by argon bubbling were not required during the reactions. Furthermore, the concentrations of reactants were little changed because only small amounts of additives were necessary to attain this one-pot peptide ligation. The mutated Cys residues were converted into original Ala residues by freeradical desulfurization. ${ }^{35}$ The reaction reached completion within $5 \mathrm{~h}$ and the desired full-length H1.2 (12) was obtained almost quantitatively (Figure 2C). As a result, we accomplished the total chemical synthesis of $\mathrm{H} 1.2$ in $20 \%$ total yield.

Next, we incorporated PTMs into H1.2. As candidates of modifications, we chose citrullination of Arg at 53 (R53Cit) and phosphorylation of Ser at 172 (S172ph). It was reported that the R53 site was modified to Cit by PAD4, which regulates pluripotency, and the chromatin structure became decondensed and cells were reprogrammed. ${ }^{36}$ S172ph was observed specifically during interphase and mitosis and might have an influence on the stability of chromatosome. ${ }^{37}$ However, there were no reports of creating H1.2 bearing site-specific PTMs and the influence of these PTMs of H1.2 on the binding affinity for nucleosome has not been investigated. To synthesize modified H1.2, we prepared a peptide segment of $\mathrm{H} 1.2$ bearing R53Cit (8a) or S172ph (3a) by Fmoc-SPPS (Figure S10). According to the synthetic scheme shown above, the divided peptide segments were assembled in a one-pot manner with Ru catalyst (Figure S11). After completion of peptide ligation, the Cys residues were converted into Ala residues (Figure S12). As a result, we accomplished the chemical synthesis of citrullinated H1.2 (12a) and phosphorylated H1.2 (12b) in a similar total yield to nonmodified H1.2. Thus, our facile and rapid synthetic method helped the efficient chemical synthesis of three types of full-length H1.2.

Reconstitution of chromatosomes. We examined the formation of chromatosomes using our synthetic H1.2. The recombinant $\mathrm{H} 1.2$ or synthetic H1.2 (12) was mixed with Nap1, a histone chaperone to suppress aggregation during the reconstitution of chromatosomes, ${ }^{38}$ and each mixture was incubated at $37^{\circ} \mathrm{C}$. The nucleosome solution was then added to each mixture to reconstitute chromatosomes. The synthetic H1.2 formed chromatosome in a similar way to recombinant H1.2 (Figure S13), suggesting that synthetic H1.2 was refolded properly to form the chromatosomes.
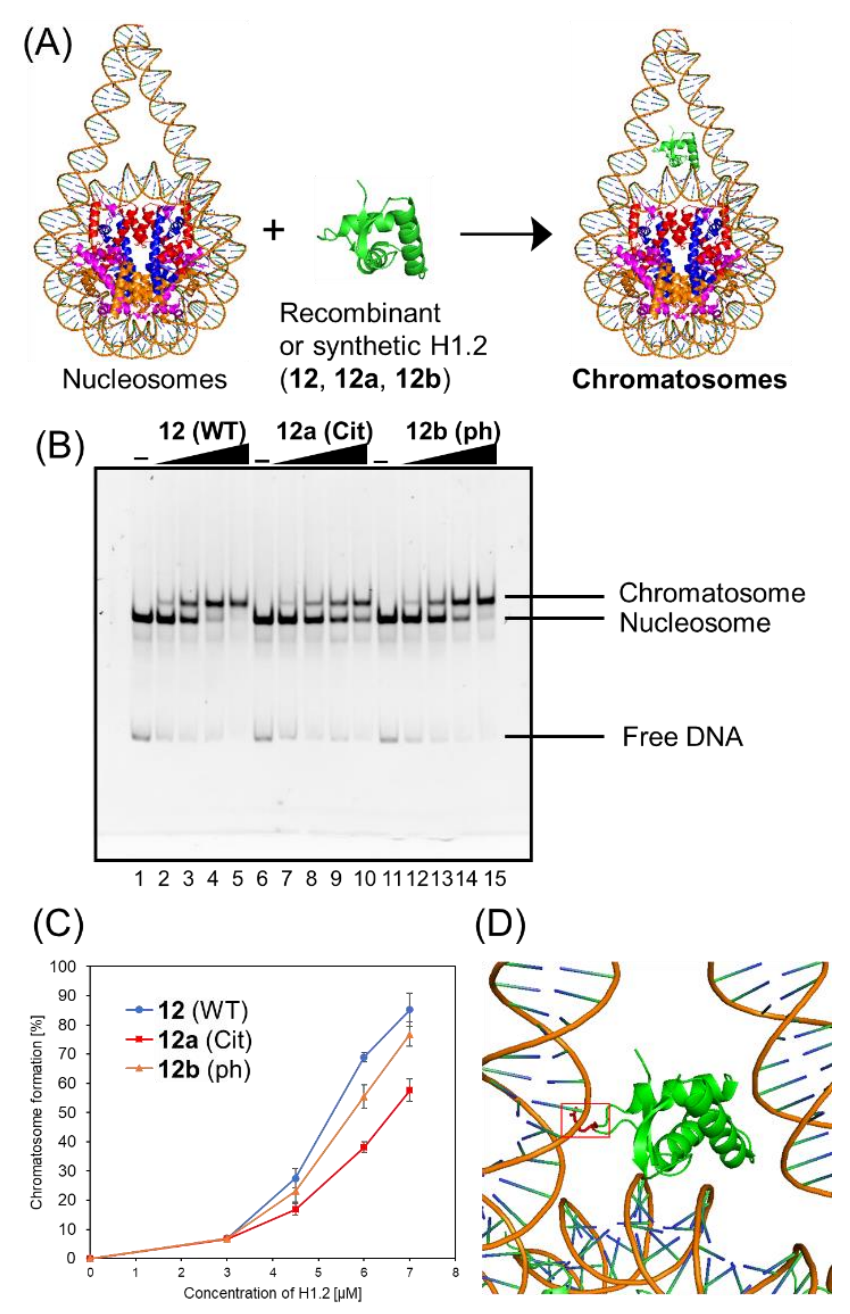

Figure 3. Gel band shift assay for reconstitution of chromatosomes. (A) Schematic representation of the reconstitution of chromatosomes. (B) Representative gel image of the H1 binding assay. Increasing amounts of wt H1.2, H1.2 bearing R53Cit, or H1.2 bearing S172ph $(0 \mu \mathrm{M}$ : lanes 1,6 and $11 ; 0.3 \mu \mathrm{M}$ : lanes 2, 7 and $12 ; 0.45 \mu \mathrm{M}$ : lanes 3, 8 and 13; $0.6 \mu \mathrm{M}$ : lanes 4, 9 and 14; $0.7 \mu \mathrm{M}$ : lanes 5, 10 and 15) were mixed with nucleosomes $(0.1 \mu \mathrm{M})$ in the presence of Nap1 $(0.3 \mu \mathrm{M})$. After incubation at $37{ }^{\circ} \mathrm{C}$, the complexes were detected by nondenaturing 5\% PAGE with ethidium bromide staining. (C) Quantification of EMSAs using synthetic H1.2s. (D) Position of R42 (red) of $X$. laevis histone $\mathrm{H} 1.0 \mathrm{~b}$, which is identical to $\mathrm{R} 53$ of human H1.2, in chromatosomes (PDB: 5NL0). ${ }^{39}$

Next, we investigated the effect of R53Cit or S172ph on the binding affinity for nucleosome by electrophoretic mobility shift assay (EMSA) (Figure 3B). There was a slight difference between 12 and $\mathbf{1 2 b}$ with phosphorylation, but 12a with citrullination reduced its binding affinity for nucleosomes, and its conversion yield was reduced by approximately $30 \%$ compared to nonmodified H1.2 (Figure 3C). R53 interacts with the phosphate backbone of the minor groove of linker DNA in chromatosome (Figure 3D). We concluded that $\mathrm{H} 1.2$ with $\mathrm{R} 53 \mathrm{Cit}$ reduced its binding ability toward nucleosomes because of the lack of electrostatic interaction between Arg and DNA. ${ }^{36}$ Our research demonstrated for the first time the direct effect of PTMs of H1.2 using homogeneously modified H1.2. 
Chemical synthesis of HP1 $\alpha$. To broaden the applicability of the Ru-catalyzed alloc removal for chemical protein synthesis, we selected heterochromatin protein $1 \alpha$ (HP1 $\alpha$ ) as a second target. This "non-histone chromosomal protein" contains two globular domains, a chromo domain (CD) and a chromo shadow domain (CSD), which are connected by a hinge region (HR) ${ }^{40-43} \mathrm{CD}$ recognizes the trimethylation of Lys 9 within histone H3 (H3K9me3), which is a hallmark of transcriptionally silenced chromatin. ${ }^{44} \mathrm{CSD}$ is a domain responsible for self-dimerization of HP1 $\alpha$, and also provides the interface to interact with proteins bearing the PXVXL/I binding motif, such as shugoshin 1 (Sgo1). ${ }^{45}$ In the presence of H3K9me3, CD interacts with this modification and CSD forms intermolecular bridging, which condenses chromatin to form transcriptionally silenced states. ${ }^{46}$ HP1 $\alpha$ was reported to be more extensively decorated with PTMs than other HP1 homologues (HP1 $\beta$ and HP1 $\gamma),{ }^{47}$ and these PTMs affected the interaction pattern, distribution, and localization of HP1 $\alpha .{ }^{43}$ Therefore, the elucidation of the functions of PTMs on HP1 $\alpha$ was essential to understand the behavior of dynamic chromatin.

In accordance with Figure 4, full-length HP1 $\alpha$ was divided into five peptide segments (peptides 13, 14', 15, 16, 20), and each fragment was synthesized by Fmoc-SPPS (Figure S14). C-Terminal Asp 58, bearing thioesters of peptide 20, was protected by the allyl group ${ }^{48}$ to inhibit hydrolysis of thioesters and isomer formation via intramolecular cyclization. ${ }^{49}$ The N-terminal Cys of peptides 14' $^{\prime}$ and 15 were protected with the alloc groups, and acetamidomethyl $(\mathrm{acm})$ groups were introduced at $\mathrm{N}$-terminal Cys of peptide 16 and inner Cys of peptides 13 and 14'. However, we encountered a difficulty in the synthesis of peptide 14' without any solubilizing tag. This peptide contained many hydrophobic amino acids and a small number of basic amino acids, and was barely soluble especially in acidic aqueous solutions, which prevented the conversion of C-terminal acyl hydrazides into thioesters. To improve the solubility, we decided to install a solubilizing tag bearing phenylacetamidomethyl (phacm) group, which was removed in the same deprotection method as Acm groups. ${ }^{12 \mathrm{e}}$ Alloc-Cys(Phacm-Fmoc)-OH was newly synthesized (see the Supporting Information), and incorporated during Fmoc-SPPS in place of Fmoc-Cys(Acm)-OH, and three protected Arg residues were coupled (Scheme S1). After the deprotection of the alloc groups with $\mathrm{Pd}\left(\mathrm{PPh}_{3}\right)_{4}$ complexes, the remaining amino acids were coupled and the peptide was cleavage with TFA cocktails. The crude peptide 14 bearing three Arg residues was directly dissolved in acidic buffer, the acyl hydrazine was successfully converted into thioesters using acetylacetone and 4mercaptophenol, ${ }^{50}$ and we obtained peptide 14 bearing a solubilizing tag (Figure S14).

Peptides 13, 14, 15, and 16 were assembled in a one-pot manner using Ru-4 catalyst (Figures 4B and S15). The removal of the alloc groups proceeded with only $20 \mathrm{~mol} \%$ of Ru-4, and, after three NCL steps and two deprotection steps, the desired intermediate peptide $\mathbf{1 7}$ was obtained in $35 \%$ isolated yield (Figure S16). Free-radical desulfurization was then conducted to convert mutated Cys residues into original Ala residues (Figure S17). To remove the Acm groups and solubilizing tag, we first employed sodium tet- rachloropalladate $\left(\mathrm{Na}_{2} \mathrm{PdCl}_{4}\right){ }^{5 e, 12 \mathrm{~d}}$ As a result, after the addition of this Pd complex (5.0 equiv. toward peptide 18), some aggregates appeared in the reaction solution, which led to low recovery rates after HPLC purification.

Therefore, we used silver acetate (AgOAc) instead of $\mathrm{Na}_{2} \mathrm{PdCl}_{4}{ }^{51}$ This time, aggregates were not observed after the overnight reaction and the desired product 19 was isolated in 62\% yield (Figure S18). Finally, peptide 20 was ligated with peptide 19, and the reaction reached completion after $2 \mathrm{~h}$ (Figure 4C). When we successively added $\mathrm{Pd} / \mathrm{TPPTS}$ complex to remove the ally groups at Asp 58, some aggregates appeared again. When $\mathbf{R u - 4}$ was used for deprotection of the allyl group, the desired full-length HP1 $\alpha$ (21) was obtained without aggregation in 53\% isolated yield. These results suggested that it would be difficult to apply Pd complexes for the total chemical synthesis of HP1 $\alpha$ due to the aggregation probably caused by intermolecular bridging of inner Cys of HP1 $\alpha$ by Pd complexes and hydrophobic interactions among CSDs, which emphasized that the choice of metal complex is important to produce desired proteins in a chemical method.

Preparation of modified HP1 $\alpha$. We then tried to create HP1 $\alpha$ bearing specific PTMs. First, we focused on phosphorylations decorated at Ser residues of the N-terminal tail of HP1 $\alpha$ (S11, S12, S13, S14). ${ }^{52}$ These modifications were reported to increase its binding affinity toward H3K9me3 and disturb the interaction between DNA and basic patches in HR of HP1 $\alpha$ (residues 89-91 and residues 104-107),53 which increased its specificity toward nucleosomes containing H3K9me3 marks. S14ph is a prerequisite for the phosphorylation of its neighboring serine residues, but the effect of the number of phosphorylated Ser at Nterminal tail had not been investigated. Moreover, it was reported that Ser residues of HR in mouse HP1 $\alpha$ are phosphorylated in cells. ${ }^{52,54}$ S95ph mediated by NDR1 kinase is required for mitotic progression and Sgo1 binding to mitotic centromeres, ${ }^{55}$ and Aurora B kinase also mediates mitotic phosphorylation of HP1 $\alpha$ at HR (mainly at S92), 56 which dissociates HP1 $\alpha$ from mitotic chromatin and reduces its DNA-binding activity. To investigate the effect of the phosphorylation at HR on the DNA binding affinity of HP1 $\alpha$, phosphorylated HP1 $\alpha$ was prepared by simultaneous expression of HP1 $\alpha$ and specific kinases in Escherichia coli. $^{52,56}$ However, the possibility of phosphorylations at other Ser sites by kinases could not be excluded and homogeneous HP1 $\alpha$ bearing site-specific phosphorylations were required to investigate the precise properties of each phosphorylation site. On the other hand, although the responsible enzymes had not been discovered, Lys 91 and Lys 106 in basic areas of HP1 $\alpha$ were reported as decorated with acetylation, ${ }^{47}$ but the influence of acetylation on DNA binding was still unclear. To construct homogeneously phosphorylated or acetylated $\mathrm{HP} 1 \alpha$, we newly synthesized peptides 15a, 16a, 16b, 16c, 20a, and 20b by Fmoc-SPPS (Figure S14). By following the synthetic scheme shown in Figure 4, 

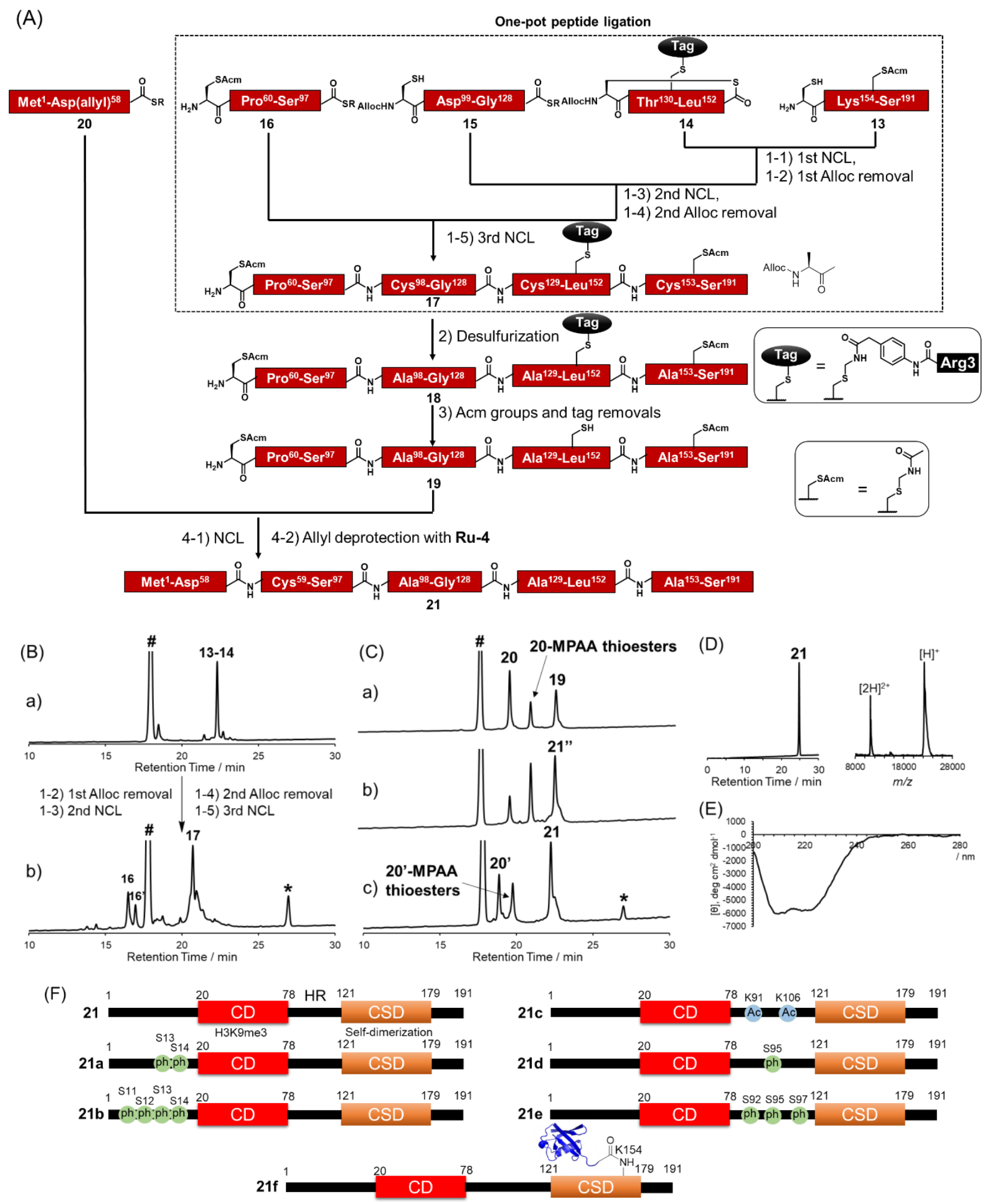

Figure 4. Chemical synthesis of HP1 $\alpha$ using the Ru catalyst. (A) Synthetic strategy. 1) NCL condition: peptides (2 mM), MPAA (100 $\mathrm{mM}$ ) in denaturing buffer at $\mathrm{pH} 7.0,37^{\circ} \mathrm{C}$. Removal condition: Ru-4 (20 mol\%), $\left.37^{\circ} \mathrm{C}, 20 \mathrm{~min} .2\right)$ Peptide (0.8 mM), TCEP (300 $\mathrm{mM})$, GSH (150 mM), VA-044 (20 mM) in denaturing buffer at pH 7.0. 3) Peptide (0.5 mM), AgOAc (30 mM), $\mathrm{H}_{2} \mathrm{O} / \mathrm{AcOH}(1: 1), 37^{\circ} \mathrm{C}$, overnight. 4) NCL condition: peptides (1.5 mM), MPAA (100 mM) in denaturing buffer at pH 7.0, $37{ }^{\circ} \mathrm{C}$. Removal condition: Ru-4 (20 mol\%), $37^{\circ} \mathrm{C}, 20 \mathrm{~min}$. (B) Reaction tracking of the one-pot ligation with catalytic amount of Ru-4 (20 mol\%) for the alloc deprotection by analytical HPLC (gradient: $15-51 \%$ for $30 \mathrm{~min}$ ) at $220 \mathrm{~nm}$. a) $1 \mathrm{st}$ NCL $(t=4 \mathrm{~h}$ ). b) 3rd NCL after overnight reaction. (C) Reaction tracking of NCL between peptides 19 and 20, followed by the allyl removal with Ru-4 (20 mol\%) by analytical HPLC (gradient: $15-51 \%$ for $30 \mathrm{~min}$ ) at $220 \mathrm{~nm}$. a) NCL ( $t=3 \mathrm{~min}$ ). b) NCL ( $t=1.5 \mathrm{~h}$ ). c) Allyl deprotection with Ru-4. (D) HPLC profile (gradient $15-51 \%$ for $30 \mathrm{~min}$ ) and MALDI-TOF mass spectrum of purified peptide 21. Calculated mass of 21 [M+H] ${ }^{+}$: 22225.7; Mass Found [M+H]+: 22226.0. (E) CD spectrum of 21. (F) Chemically synthesized HP1 $\alpha$ with PTMs in this study. 21: HP1 $\alpha$ without PTMs. 21a and 21b: HP1 $\alpha$ with PTMs at N-terminus. 21c, 21d, and 21e: HP1 $\alpha$ with PTMs at HR. 21f: HP1 $\alpha$ with Ub at K154 in CSD. 
we constructed double phosphorylated (S13ph, S14ph) (21a) and quadruple phosphorylated (S11ph, S12ph, S13ph, S14ph) (21b) HP1 $\alpha$ at the N-terminus, singly phosphorylated (S95ph) (21c) and triple phosphorylated (S92ph, S95ph, S97ph) (21d) HP1 $\alpha$ at HR and double acetylated (K91ac, K106ac) (21e) HP1 $\alpha$ at HR (Figures 4, S16, S17, S18).

(A)

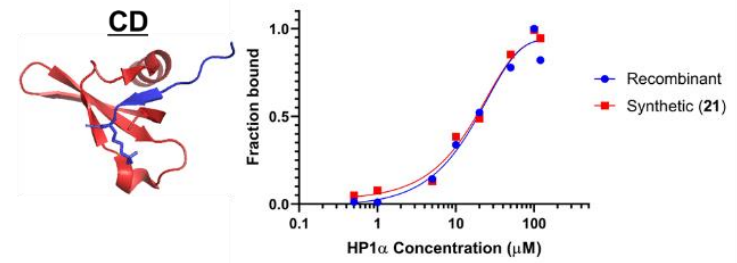

(B)

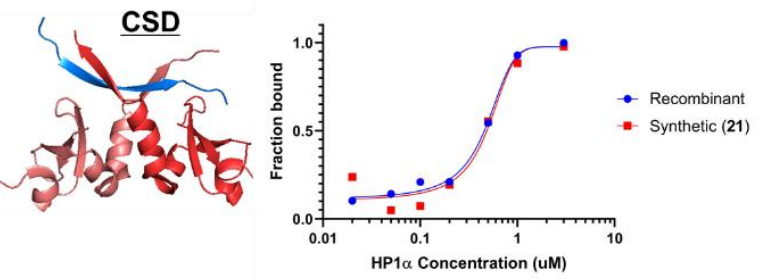

Figure 5. Fluorescence polarization assay. (A) Binding of CD of recombinant or synthesized HP1 $\alpha$ with fluorescein-label H3 peptide with K9me3. (red: CD of HP1 $\alpha$, blue: N-terminal tail of histone $\mathrm{H} 3$ with K9me3, PDB: 3FDT). (B) Binding of CSD of recombinant or synthesized HP1 $\alpha$ with fluorescein-label Sgo1 peptide. (red: CSD of HP1 $\beta$, blue: Sgo1 peptide, PDB: 3Q6S).

We also focused on the PTMs decorated at CSD of HP1 $\alpha$. Ubiquitination (Ub) at K154 of HP1 $\alpha$ was a unique modification among HP1 homologues, and this modification promotes degradation of HP1 $\alpha$ through the autophagy pathway, which decondenses chromatin structure to enable efficient DNA repair. ${ }^{57} \mathrm{~K} 154$ is located at the dimerization interface of CSDs, and we hypothesized that steric hindrance of Ub might disturb the dimerization of CSD and interaction with proteins bearing the PXVXL/I binding motif, which promoted an open chromatin structure. To create HP1 $\alpha$ with $\mathrm{Ub}$ at K154, we synthesized peptides 22 and 23 (Figure S20). Peptide 22, which contained the Cterminal region of $\mathrm{Ub}$ linked by isopeptide linkage at K154 of HP1 $\alpha$, was prepared in a similar way to previous research. ${ }^{58}$ To achieve one-pot synthesis by combining the convergent method, peptide 24, bearing acyl hydrazide at its C-terminus, was also synthesized (Figure S20). As shown in Scheme S2, peptides 14, 22, 23, and 16-24 were assembled in a one-pot manner to obtain peptide 25 (Figure S21, S22), and, after desulfurization followed by the removal of the Acm groups and a solubilizing tag (Figures S23, S24), peptide $\mathbf{2 7}$ was ligated with peptide $\mathbf{2 0}$ followed by allyl deprotection with Ru-4 to afford HP1 $\alpha$ ubiquitinated at K154 (21f) (>30 kDa) (Figures 4, S25). Finally, we obtained five kinds of full-length HP1 $\alpha$ bearing the different patterns of PTMs. We note that these proteins were rapidly prepared thanks to one-pot ligation of divided peptide fragments using $\mathbf{R u}-\mathbf{4}$ catalyst.
Fluorescence anisotropy assay. After refolding of chemically synthesized HP1 $\alpha$ by dialysis, we first tested the interaction of the CD of HP1 $\alpha$ with H3K9me3 peptide bearing fluorescein at its $\mathrm{N}$-terminus (residues $1-20$ ) by fluorescence polarization (FP). The binding affinity of $\mathbf{2 1}$ [dissociation constant $\left.\left(K_{\mathrm{d}}\right): 23 \mu \mathrm{M}\right]$ was almost the same as that of recombinant HP1 $\alpha\left(K_{\mathrm{d}}: 19 \mu \mathrm{M}\right)$ (Figure $\left.5 \mathrm{~A}, \mathrm{~S} 26\right)$, indicating that the CD of synthetic HP1 $\alpha$ properly recognized $\mathrm{H} 3 \mathrm{~K} 9 \mathrm{me} 3$ peptide. We further examined the binding of Sgo1 peptide (residues 446-466) bearing fluorescein toward dimerized interfaces of HP1 $\alpha$ CSDs. 21 showed a similar a $K_{\mathrm{d}}$ value $\left(K_{\mathrm{d}}: 0.47 \mu \mathrm{M}\right)$ toward Sgo1 peptide as the recombinant one $\left(K_{\mathrm{d}}: 0.51 \mu \mathrm{M}\right)$ (Figures $\left.5 \mathrm{~B}, \mathrm{~S} 26\right)$. These results indicated that our chemically synthesized HP1 $\alpha$ was properly refolded after dialysis, and recognized H3K9me3 modification and PXVXL/I binding motif through CD and dimerized CSDs, respectively. Next, we investigated the influence of Ub at K154 of HP1 $\alpha$ on the binding affinity toward the Sgo1 peptide. The $K_{\mathrm{d}}$ value of 21f was increased to $1.87 \mu \mathrm{M}$ (Figure S26), suggesting that the affinity was reduced to 3.9-fold compared to canonical HP1 $\alpha$. We reasoned that Ub modification disturbed the intermolecular dimerization of HP1 $\alpha$ CSDs probably because of the steric hindrance of Ub. It was envisaged that HP1 $\alpha$ CSD further reduced its affinity toward its CSD by being attached with Ub chains, which could induce the decompaction of chromatin structure.

Investigation of DNA binding ability of modified HP1 $\alpha$. The high binding affinity of HP1 $\alpha$ against DNA is a characteristic feature over other HP1 homologues, HP1 $\beta$ and HP $1 \gamma^{52}$ To investigate the relationship between PTMs on the N-terminus, HR, or CSD and DNA-binding ability of HP1 $\alpha$, EMSAs was conducted using 193-bp DNA. In this assay, HP1 $\alpha$ without PTMs efficiently bound 601 DNA, and its $K_{\mathrm{d}}$ value was $0.75 \mu \mathrm{M}$ (Figure $6 \mathrm{~A}, \mathrm{~B}$ ), which was consistent with the previous results. ${ }^{53} \mathbf{2 1 a}$, containing doubly phosphorylated Ser residues at its N-terminus, showed slightly higher $K_{\mathrm{d}}$ value compared to normal HP1 $\alpha$ ( $K_{\mathrm{d}}$ : $1.32 \mu \mathrm{M}$ ), but $\mathbf{2 1 b}$, containing quadruple phosphorylation, significantly lowered the DNA-binding ability of HP1 $\alpha\left(K_{\mathrm{d}}\right.$ : $4.67 \mu \mathrm{M}$ ) (Figure 6A, B). This result indicated that the number of phosphorylated Ser residues at the N-terminus of HP1 $\alpha$ had an impact on its DNA-binding ability. We also evaluated the other PTMs on HR or CSD. 21c, with double acetylation of Lys at HR, slightly lowered its DNA-binding ability ( $K_{\mathrm{d}}: 1.79 \mu \mathrm{M}$ ) (Figure 6A, C), but these PTMs were found to be littele influential. Surprisingly, 21d and 21e with Ser phosphorylation at HR had little influence on the affinity of HP1 $\alpha$ toward DNA [ $K_{\mathrm{d}}: 0.95 \mu \mathrm{M}(\mathbf{2 1 d}), K_{\mathrm{d}}: 0.82$ $\mu \mathrm{M} \mathrm{(21e)]} \mathrm{(Figure} \mathrm{6A,} \mathrm{C),} \mathrm{although} \mathrm{basic} \mathrm{patches} \mathrm{on} \mathrm{HR} \mathrm{of}$ HP1 $\alpha$ were the main responsible sites for the interaction with DNA. ${ }^{53}$ Considering that phosphorylation at HR mainly occurred during mitosis and HP1 $\alpha$ dissociated from mitotic chromatin, ${ }^{55,56}$ some interacting partners for these phosphorylation sites or other factors might induce its dissociation. We found that the binding affinity of $21 \mathbf{f}$ with $\mathrm{Ub}$ at CSD was almost identical to that of normal $\operatorname{HP} 1 \alpha\left(K_{\mathrm{d}}\right.$ : $0.71 \mu \mathrm{M}$ ) (Figure 6A, C). 
(A)

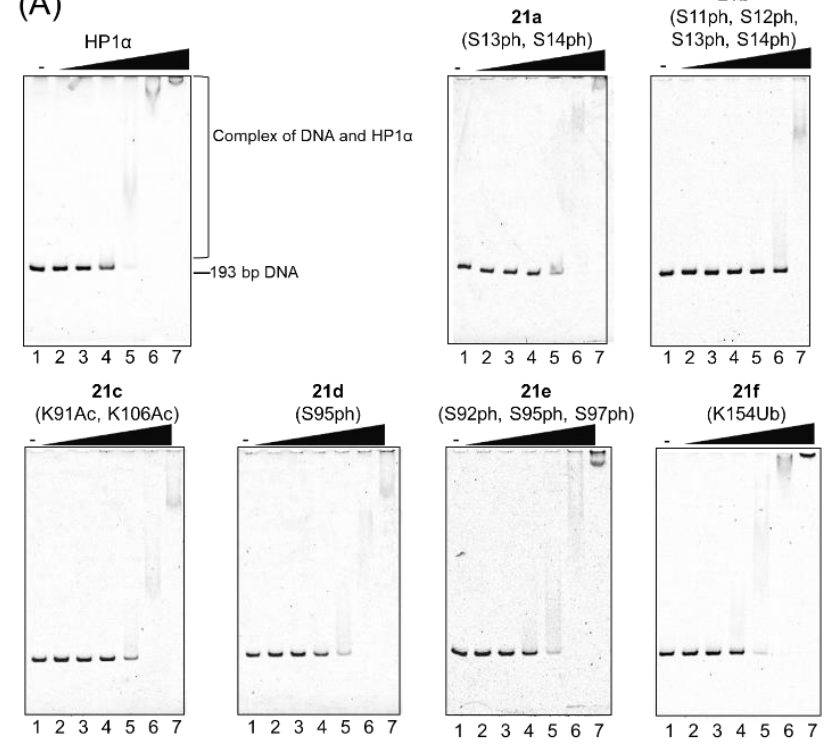

(B)

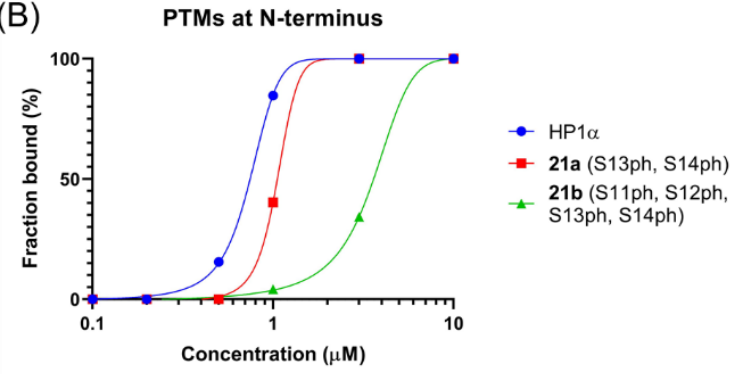

(C)

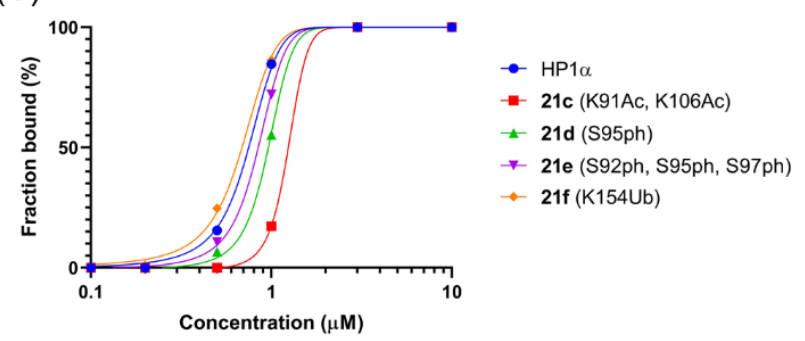

Figure 6. EMSAs using chemically synthesized HP1 $\alpha$ with PTMs. (A) Representative gel images of the binding of HP1 $\alpha$ toward DNA. Various concentrations of HP1 $\alpha$ were incubated with 193-bp DNA. The complexes were analyzed by $8 \%$ native-PAGE and visualized with SYBR Gold. Quantification of the EMSAs using HP1 $\alpha$ with PTMs at (B) N-terminus, (C) HR or CSD.

To summarize, the sites and the number of phosphorylated Ser residues were responsible for control of the DNA binding ability of HP1 $\alpha$. Next, we analyzed the particle size of complexes composed of DNA and HP1 $\alpha$ by dynamic light scattering (DLS). HP1 $\alpha$ without PTMs formed large particles with DNA, and its diameter was around 1,000 nm (Figure 7). 21a also formed large particles with around $1,000 \mathrm{~nm}$ diameter. However, 21b completely inhibited the formation of complexes, and we could not detect large particles (Figure 7), which would be caused by the lower DNA-binding ability of HP1 $\alpha$ bearing four consecutive phosphorylation at N-terminus. In interphase, HP1 $\alpha$ is decorated by phosphorylation mainly at the $\mathrm{N}$-terminus region, ${ }^{55}$ which reduces its DNA-binding ability to prevent non-specific binding to nucleosomes bearing unmodified H3K9. ${ }^{2}$ However, in mitosis, N-terminal phosphorylations are removed by phosphatases, which would lead to it reacquiring its DNA-binding ability, and mainly HR is decorated by phosphorylation. ${ }^{5}$ Considering the little influence of phosphorylation at HR on its DNA binding ability, we assume that a portion of HP1 $\alpha$ bearing Ser phosphorylation at HR could localize to the centromere during metaphase ${ }^{59}$ involving an interaction between CSD of HP1 $\alpha$ and inner centromere protein (INCENP), ${ }^{45}$ and would help accurate chromosome alignment and mitotic progression. ${ }^{55}$ The importance of the number and location of phosphorylation was clarified by our homogeneously prepared HP1 $\alpha$ bearing site-specific PTMs.

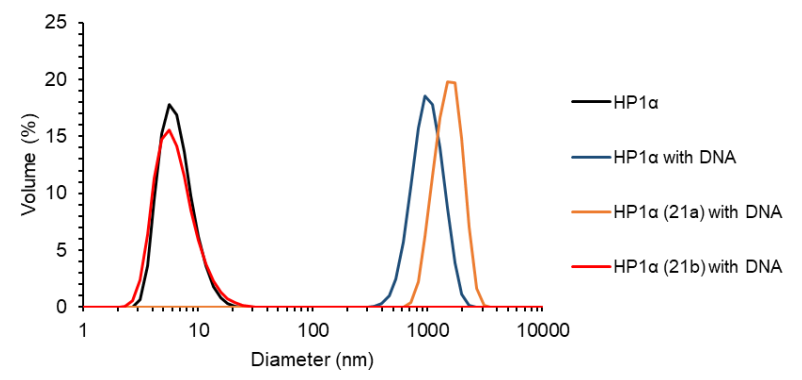

Figure 7. DLS measurement of complexes composed of 601 DNA (50 nM) and modified HP1 $\alpha(10 \mu \mathrm{M})$.

\section{CONCLUSION}

We attained the total chemical synthesis of histone H1.2 and HP1 $\alpha$, which regulate heterochromatin structure, through one-pot multiple peptide ligation with Ru catalyst. Generally, it had been difficult to perform metal-catalyzed reactions on peptides or proteins. However, Ru-4 and $\mathbf{R u}-$ 10 showed excellent catalytic activity even under aerobic conditions, and the TONs of Ru-4 and Ru-10 exceeded 70 even in the presence of 5,000 equiv. of MPAA, which could not be accomplished by other metal complexes. We also found that MPAA functioned as a good scavenger for intermediate $\pi$-allyl $\mathrm{Ru}$ during the alloc deprotection and prevented the allyl transfer to functional groups of peptides or proteins. Moreover, the Ru catalyst was simultaneously deactivated during the alloc removal through ligand exchange with MPAA to form a binuclear Ru complex. Our newly synthesized Ru-10 showed the highest catalytic activity and greatest stability toward thiol moieties, suggesting that this $\mathrm{Ru}$ complex could be used for the other applications, such as cellular experiments. However, we employed Ru-4 for chemical protein synthesis due to its facile deactivation by MPAA. We successfully synthesized three kinds of full-length H1.2 and seven kinds of HP1 $\alpha$ with different patterns of PTMs through one-pot peptide ligation using Ru-4 catalyst. Especially for the synthesis of HP1 $\alpha$, by switching the kinds of metal complexes, we prevented the generation of aggregates during protein synthesis. The chromatosomes were reconstituted by three types of our synthetic H1.2, and R53Cit contributed to the reduction of its binding affinity for nucleosome. In the evaluation of modified $\mathrm{HP} 1 \alpha$, Ub at K154 reduced its binding affinity toward the PXVXL/I binding motif by disrupt- 
ing CSD dimerization. Moreover, four consecutive phosphorylations at the N-terminus of HP1 $\alpha$ significantly reduced its DNA-binding ability and disrupted the formation of complexes with DNA, which was not observed using HP1 $\alpha$ containing other patterns of PTMs. Our homogeneously prepared HP1 $\alpha$ contributed to the understanding of precise natures of PTMs of H1.2 or HP1 $\alpha$, which could not be achieved by using heterogeneously modified proteins by enzymatic methods. The elucidations of PTMs decorated on not only core histone proteins but other histones and non-chromosomal proteins are essential to gain deeper insights in epigenetics. We believe that our facile and efficient synthetic method using Ru catalyst will accelerate the preparation of various proteins bearing site-specific PTMs and facilitate our understanding of biological phenomena.

\section{EXPERIMENTAL SECTION}

One-pot five-segment ligation to afford full-length histone H1.2. Peptide 3 ( $374 \mathrm{nmol}, 3.65 \mathrm{mg}$ ) was dissolved in $187 \mu \mathrm{L}$ NCL buffer (6 M Gn.HCl, $0.2 \mathrm{M} \mathrm{NaH}_{2} \mathrm{PO}_{4}, 100 \mathrm{mM}$ MPAA at pH 7.0) (the concentration of peptide was 2.1 $\mathrm{mM})$. Then, 1.05 equiv. of a powdered peptide $4(392 \mathrm{nmol}$, $2.74 \mathrm{mg}$ ) was added to the reaction mixture and it was stirred at $37^{\circ} \mathrm{C}$ for $2 \mathrm{~h}$ under argon atmosphere (first NCL). Then, $2.5 \mu \mathrm{L} \mathbf{R u}-4$ solution in acetonitrile $(30 \mathrm{mM})(20$ mol\%) was added to the reaction solution and the mixture was stirred for $30 \mathrm{~min}$ at $37{ }^{\circ} \mathrm{C}$ (first deprotection). Then, $3.0 \mu \mathrm{L}$ TCEP solution $(500 \mathrm{mM})$ was added. After stirring $10 \mathrm{~min}$, a powdered peptide 6 ( $406 \mathrm{nmol}, 1.74 \mathrm{mg}$ ) and the reaction solution was stirred at $37{ }^{\circ} \mathrm{C}$ for $1.5 \mathrm{~h}$ (second NCL). $2.5 \mu \mathrm{L}$ Ru-4 solution in acetonitrile $(30 \mathrm{mM})(20$ mol\%) was added to the reaction solution and the mixture was stirred for $30 \mathrm{~min}$ at $37{ }^{\circ} \mathrm{C}$ (second deprotection). Then, $2.0 \mu \mathrm{L}$ TCEP solution $(500 \mathrm{mM})$ was added. After stirring $10 \mathrm{~min}$, a powdered peptide $8(409 \mathrm{nmol}, 1.05 \mathrm{mg})$ and the reaction solution was stirred at $37^{\circ} \mathrm{C}$ for $2 \mathrm{~h}$ (third NCL). Then, $2.5 \mu \mathrm{L} \mathbf{R u}-\mathbf{4}$ solution in acetonitrile $(30 \mathrm{mM})$ (20 mol\%) was added to the reaction solution and the mixture was stirred for $30 \mathrm{~min}$ at $37^{\circ} \mathrm{C}$ (third deprotection). Finally, powdered peptide 10 (516 nmol, $3.00 \mathrm{mg}$ ) and $15.0 \mu \mathrm{L}$ TCEP $(500 \mathrm{mM})$ were added and the $\mathrm{pH}$ was adjusted to around 7.0. The mixture was stirred at $37^{\circ} \mathrm{C}$ for 2 $\mathrm{h}$ (fourth NCL). For analysis of each reaction, $1.0 \mu \mathrm{L}$ aliquot from each reaction mixture was treated with a $15.0 \mu \mathrm{L}$ MESNa aq $(1.0 \mathrm{M})$ and $2.0 \mu \mathrm{L}$ TCEP solution $(500 \mathrm{mM})$, followed by stirring for $10 \mathrm{~s}$ and injection into analytical HPLC. The peptide solution was diluted by a mixture of water/acetonitrile containing $0.1 \%$ TFA and purified by HPLC to afford the desired product $11(2.52 \mathrm{mg}, 88 \mathrm{nmol})$ in $23 \%$ isolated yield. Peptide 11a with citrullination and peptide 11b with phosphorylation were prepared in a similar way on a $260 \mathrm{nmol}$ scale. 11a was isolated in $22 \%$ yield (1.63 mg, $57 \mathrm{nmol})$, and $\mathbf{1 1 b}$ was isolated in $13 \%$ yield $(0.98 \mathrm{mg}, 35 \mathrm{nmol})$.

Reconstitution of chromatosomes. Each amount of $\mathrm{H} 1.2$ $(12,12 a$, and $12 b)$ were mixed with the nucleosomes $(0.2$ $\mu \mathrm{M})$, which was formed with the 193 bp 601 DNA in the presence of Nap1 $(0.3 \mu \mathrm{M})$, in $10 \mu \mathrm{L}$ of the reaction buffer, containing $35 \mathrm{mM}$ Tris- $\mathrm{HCl}$ (pH 8.0), $70 \mathrm{mM} \mathrm{NaCl}, 0.01 \mathrm{mM}$ PMSF, $0.05 \mathrm{mM}$ EDTA, 5\% glycerol, $1.2 \mathrm{mM}$ dithiothreitol, $1.1 \mathrm{mM} 2$-mercaptoethanol, and $5 \mu \mathrm{g} / \mathrm{ml}$ bovine serum albumin. After incubation at $37^{\circ} \mathrm{C}$ for $30 \mathrm{~min}, 2 \mu \mathrm{L}$ of $30 \%$ sucrose was added and the samples were loaded onto $5 \%$ native polyacrylamide gels in $1 \times$ Trisborate-EDTA (TBE) buffer $(90 \mathrm{mM}$ Tris base, $90 \mathrm{mM}$ boric acid and $2 \mathrm{mM}$ EDTA). The gel was stained with ethidium bromide. The band intensities of the chromatosomes and nucleosomes were quantitated with a LAS-4000 image analyzer (GE Healthcare) using MultiGauge ver. 3.2 (Fujifilm) and the efficiency of the formation of the chromatosomes was calculated.

NCL and following the allyl removal with Ru-4 to afford 21. Peptide $20(0.50 \mathrm{mg}, 26 \mathrm{nmol})$ was dissolved in 17.5 $\mu \mathrm{L}$ NCL buffer ( $6 \mathrm{M} \mathrm{Gn.HCl,} 0.2 \mathrm{M} \mathrm{NaH}_{2} \mathrm{PO}_{4}, 100 \mathrm{mM}$ MPAA, $2 \mathrm{mM}$ TCEP at $\mathrm{pH} 7.0)$. A powdered peptide $20(0.27 \mathrm{mg}$, $32 \mathrm{nmol}$ ) was added to the reaction mixture and it was stirred at $37{ }^{\circ} \mathrm{C}$ for $2 \mathrm{~h}$ under argon atmosphere. Then, 0.6 $\mu \mathrm{L} \mathbf{R u}-\mathbf{4}$ solution in acetonitrile $(10 \mathrm{mM})$ was added to the reaction solution and the mixture was stirred for $20 \mathrm{~min}$ at $37^{\circ} \mathrm{C}$. To the reaction mixture was added 5.0 $\mu \mathrm{L}$ TCEP solution $(500 \mathrm{mM})$ to reduce disulfide bonds. After stirring for $5 \mathrm{~min}$, the reaction solution was diluted with a mixture of water/acetonitrile containing $0.1 \%$ TFA and purified by HPLC to afford the desired full-length HP1 $\alpha 21(0.37 \mathrm{mg}$, $14 \mathrm{nmol}$ ) in 53\% isolated yield. Proteins 21a, 21b, 21c, 21d, and 21e were prepared in a similar way. 21a was isolated in $53 \%$ yield $(0.74 \mathrm{mg}, 28 \mathrm{nmol})$ from a $53 \mathrm{nmol}$ scale, 21b was isolated in $46 \%$ yield $(0.32 \mathrm{mg}, 12 \mathrm{nmol})$ from a $26 \mathrm{nmol}$ scale, 21c was isolated in $60 \%$ yield $(0.80$ $\mathrm{mg}, 27 \mathrm{nmol}$ ) from a $45 \mathrm{nmol}$ scale, 21d was isolated in $60 \%$ yield $(1.06 \mathrm{mg}, 40 \mathrm{nmol})$ from a $67 \mathrm{nmol}$ scale, $21 \mathrm{e}$ was isolated in $70 \%$ yield $(0.93 \mathrm{mg}, 31 \mathrm{nmol})$ from a 44 $\mathrm{nmol}$ scale, and $\mathbf{2 1 f}$ was isolated in $31 \%$ yield $(0.41 \mathrm{mg}, 11$ $\mathrm{nmol}$ ) from a $36 \mathrm{nmol}$ scale.

Measurement of fluorescence anisotropy. To analyze the interaction between $\mathrm{H} 3 \mathrm{~K} 9 \mathrm{me} 3$ peptide and $\mathrm{CD}$ of $\mathrm{HP} 1 \alpha$, to $4.5 \mu \mathrm{L} \mathrm{HP} 1 \alpha$ solution at different concentrations in binding buffer [20 mM Tris- $\mathrm{HCl}$ (pH 7.5), $100 \mathrm{mM} \mathrm{NaCl}, 2 \mathrm{mM}$ 2-mercaptoethanol] was added $0.5 \mu \mathrm{L}$ fluoresceinconjugated H3K9me3 peptide solution $(1 \mu \mathrm{M})$. The final concentrations of the mixtures of HP1 $\alpha$ were $0.5,1,5,10$, $20,50,100$, and $120 \mu \mathrm{M}$. The mixtures were incubated at $25^{\circ} \mathrm{C}$ for $30 \mathrm{~min}$. The samples were transferred to a Nonbinding 384 well Black Plate (Greiner Bio-one) and the polarization was measured by SpectraMax M5 (Molecular Device) (excitation: $485 \mathrm{~nm}$, detection: $525 \mathrm{~nm}$ ). To analyze the interaction between Sgo1 peptide and CSD of HP1 $\alpha$, to $4.5 \mu \mathrm{L}$ HP $1 \alpha$ solution at different concentrations in the binding buffer was added $0.5 \mu \mathrm{L}$ fluoresceinconjugated Sgo1 peptide solution $(200 \mathrm{nM})$. The final concentrations of the mixtures of HP1 $\alpha$ were $0.02,0.05,0.1$, $0.2,0.5,1$, and $3 \mu \mathrm{M}$ and 10 , and $15 \mu \mathrm{M}$ only for 21f. After incubation at $25{ }^{\circ} \mathrm{C}$ for $30 \mathrm{~min}$, the polarization was measured by SpectraMax M5 (Molecular Device) (excitation: $485 \mathrm{~nm}$, detection: $525 \mathrm{~nm}$ ). Curve-fitting was performed with Graphpad Prism 8 software.

Electrophoretic mobility shift assays (EMSAs). Each amount of HP1 $\alpha$ was incubated with 0.125 pmol of $193 \mathrm{bp}$ 601 DNA in $5 \mu \mathrm{L}$ of binding buffer containing $20 \mathrm{mM}$ Tris$\mathrm{HCl}$ (pH 7.5), $50 \mathrm{mM} \mathrm{NaCl}, 1 \mathrm{mM}$ 2-mercaptoethanol for 15 min at $37{ }^{\circ} \mathrm{C}$. Then, $1 \mu \mathrm{L}$ of $30 \%$ sucrose was added, and the samples were loaded onto $8 \%$ native polyacrylamide 
gels in $0.5 \times$ TBE buffer. Gels were run at room temperature at $150 \mathrm{~V}$ for $1 \mathrm{~h}$. Gels were stained with SYBR Gold (Invitrogen), visualized using a Gel Doc EZ Imager (BIO RAD) and quantified using ImageJ. Curve-fitting was performed with Graphpad Prism 8 software.

\section{ASSOCIATED CONTENT}

\section{Supporting Information.}

The supporting information is available at free of charge at. -Experimental procedures for organic synthesis, removal of the alloc groups with metal complexes, peptide synthesis, one-pot NCL reactions, desulfurization, removal of acm groups, characterization of synthesized peptides by HPLC and MS data.

\section{AUTHOR INFORMATION}

\section{Corresponding Authors}

Gosuke Hayashi - Department of Biomolecular Engineering, Graduate School of Engineering, Nagoya University, Nagoya, 464-8603, Japan.; orcid.org/0000-0001-6853-2706; Email: hayashi@chembio.nagoya-u.ac.jp.

Akimitsu Okamoto - Department of Chemistry and Biotechnology, The University of Tokyo, 7-3-1 Hongo, Bunkyoku, Tokyo 113-8656, Japan.; Research Center for Advanced Science and Technology, The University of Tokyo, Meguroku, Tokyo 153-8904, Japan.; orcid.org/0000-0002-74186237; Email: okamoto@chembio.t.u-tokyo.ac.jp.

\section{Authors}

Naoki Kamo - Department of Chemistry and Biotechnology, The University of Tokyo, 7-3-1 Hongo, Bunkyo-ku, Tokyo 113-8656, Japan; orcid.org/0000-0002-5364-4454.

Tomoya Kujirai - Laboratory of Chromatin Structure and Function, Institute for Quantitative Biosciences, The University of Tokyo, Bunkyo-ku, Tokyo 113-0032, Japan; orcid.org/0000-0001-5547-9598.

Hitoshi Kurumizaka - Laboratory of Chromatin Structure and Function, Institute for Quantitative Biosciences, The University of Tokyo, Bunkyo-ku, Tokyo 113-0032, Japan.; Department of Biological Sciences, Graduate School of Science, The University of Tokyo, Bunkyo-ku, Tokyo 1138656, Japan; orcid.org/0000-0001-7412-3722.

Hiroshi Murakami - Department of Biomolecular Engineering, Graduate School of Engineering, Nagoya University; Institute of Nano-Life-Systems, Institutes of Innovation for Future Society, Nagoya University, Nagoya, 464-8603, Japan; orcid.org/0000-0003-2089-9263.

\section{Funding Sources}

This work was supported by the Japan Society for the Promotion of Science (JSPS) KAKENHI 18H03931, 18H05504, and 19K22245 (A.O.), 18K05313,19H05287, and 20H04704 and JST PRESTO JPMJPR19K6 (G.H.). N.K. was supported by a Research Fellow of the Japan Society for the Promotion of Science 19J13608. This work was also supported by JSPS KAKENHI 18H05504, JP18H05534, and the Platform Project for Supporting Drug Discovery and Life Science Research (BINDS) from Japan Agency for Medical Research and Development (AMED) under Grant Number JP20am0101076 and JST ERATO Grant Number JPMJER1901 (H.K.) and AMED under Grant Numbers 20he0622010h0001 (H.M.).

Notes

The authors declare no competing financial interest.

\section{ACKNOWLEDGMENT}

We thank Dr. Nozomu Suzuki (Nagoya University) to kindly allow us to measure CD spectra of HP1 $\alpha$.

\section{REFERENCES}

1. (a) Musselman, C. A.; Lalonde, M. E.; Côté, J.; Kutateladze T. G. Perceiving the epigenetic landscape through histone readers. Nat. Struct. Mol. Biol. 2012, 19, 1218-1227. (b) Bannister, A. J.; Kouzarides, T. Regulation of chromatin by histone modifications. Cell Res. 2011, 21, 381-395.

2. (a) Kent, S. B. H. Novel protein science enabled by total chemical synthesis. Protein Sci. 2018, 28, 313-328. (b) Agouridas, V.; Mahdi, O. E.; Diemer, V.; Cargoët, M.; Monbaliu, J. C. M.; Melnyk, O. Native Chemical Ligation and Extended Methods: Mechanisms, Catalysis, Scope, and Limitations. Chem. Rev. 2019, 119, 7328-7443. (c) Conibear, A. C.; Watson, E. E.; Payne, R. J.; Becker, C. F. W. Native chemical ligation in protein synthesis and semisynthesis. Chem. Soc. Rev. 2018, 47, 9046-9068. (d) Bondalapati, S.; Jbara, M.; Brik, A. Expanding the chemical toolbox for the synthesis of large and uniquely modified proteins. Nat. Chem. 2016, 8 , 407-418. (e) Bode, J. W. Chemical Protein Synthesis with the $\alpha$ Ketoacid-Hydroxylamine Ligation. Acc. Chem. Res. 2017, 50, 2104-2115.

3. H2A (a) Hayashi, G.; Sueoka, T.; Okamoto, A. In vitro and in cell analysis of chemically synthesized histone H2A with multiple modifications. Chem. Commun. 2016, 52, 4999-5002. (b) Jbara, M.; Maity, S. K.; Morgan, M.; Wolberger, C.; Brik, A. Chemical Synthesis of Phosphorylated Histone H2A at Tyr57 Reveals Insight into the Inhibition Mode of the SAGA Deubiquitinating Module. Angew. Chem., Int. Ed. 2016, 55, 4972-4976. (c) Sueoka, T.; Hayashi, G.; Okamoto, A. Regulation of the Stability of the Histone H2A-H2B Dimer by H2A Tyr57 Phosphorylation. Biochemistry 2017, 56, 4767-4772. (d) Jbara, M.: Laps, S.; Morgan, M.; Kamnesky G.; Mann, G.; Wolberger, C.; Brik, A. Palladium prompted ondemand cysteine chemistry for the synthesis of challenging and uniquely modified proteins. Nat. Commun. 2018, 9, 3154. (e) Asahina, Y.; Kawakami, T.; Hojo, H. Glycopeptide Synthesis Based on a TFA-Labile Protection Strategy and One-Pot Four-Segment Ligation for the Synthesis of O-Glycosylated Histone H2A. Eur. J. Org. Chem. 2019, 1915-1920.

4. H2B (a) Zhou, L.; Holt, M. T.; Ohashi, N.; Zhao, A.; Müller, M. M.; Wang, B.; Muir, T. W. Evidence that ubiquitylated H2B corrals hDot1L on the nucleosomal surface to induce H3K79 methylation. Nat. Commun. 2016, 7, 10589. (b) Siman, P.; Karthikeyan, S. V.; Nikolov, M.; Fischle, W.; Brik, A. Convergent chemical synthesis of histone H2B protein for the site-specific ubiquitination at Lys34. Angew. Chem., Int. Ed. 2013, 52, 8059-8063. (c) Li, J.; He, Q.; Liu, Y.; Liu, S.; Tang, S.; Li, C.; Sun, D.; Li, X.; Zhou, M.; Zhu, P.; Bi, G.; Zhou, Z.; Zheng, J. S.; Tian, C. Chemical Synthesis of K34Ubiquitylated H2B for Nucleosome Reconstitution and SingleParticle Cryo-Electron Microscopy Structural Analysis. ChemBioChem 2017, 18, 176-180.

5. H3 (a) Li, J.; Li, Y.; He, Q.; Li, Y; Li, H.; Liu, L. One-pot native chemical ligation of peptide hydrazides enables total synthesis of modified histones. Org. Biomol. Chem. 2014, 12, 5435-5441. (b) Kawakami, T.; Akai, Y.; Fujimoto, H.; Kita, C.; Aoki, Y.; Konishi, T.; Waseda, M.; Takemura, L.; Aimoto, S. Sequential Peptide Ligation 
by Combining the Cys-Pro Ester (CPE) and Thioester Methods and Its Application to the Synthesis of Histone H3 Containing a Trimethyl Lysine Residue. Bull. Chem. Soc. Jpn. 2013, 86, 690-697. (c) Qi, Y. K.; He, Q. Q.; Ai, H. S.; Guao, J.; Li, J. B. The convergent chemical synthesis of histone $\mathrm{H} 3$ protein for site-specific acetylation at Lys56 and ubiquitination at Lys122. Chem. Commun. 2017, 53, 4148-4151. (d) Shimko, J. C.; North, J. A.; Bruns, A. N.; Poirier, M. G.; Ottesen, J. J. Preparation of fully synthetic histone H3 reveals that acetyl-lysine 56 facilitates protein binding within nucleosomes. J. Mol. Biol. 2011, 408, 187-204. (e) Kamo, N.; Hayashi, G.; Okamoto, A. Chemical Synthesis of Cys-Containing Protein via Chemoselective Deprotection with Different Palladium Complexes. Org. Lett. 2019, 21, 8378-8382. (f) Nakatsu, K.; Yanase, M.; Hayashi, G.; Okamoto, A. Fmoc-Compatible and C-terminalSequence-Independent Peptide Alkyl Thioester Formation Using Cysteinylprolyl Imide. Org. Lett. 2020, 22, 4670-4674. (g) Jbara, M.; Guttmann-Raviv, N.; Maity, S. K.; Ayoub, N.; Brik, A. Total chemical synthesis of methylated analogues of histone 3 revealed KDM4D as a potential regulator of H3K79me3. Bioorg. Med. Chem. 2017, 25, 4966-4970.

6. H4 (a) Asahina, Y.; Kawakami, T.; Hojo, H. One-pot native chemical ligation by combination of two orthogonal thioester precursors. Chem. Commun. 2017, 53, 2114-2117. (b) Yu, R. R.; Mahto, S K.; Justus, K.; Alexander, M. M.; Howard, C. J.; Ottesen, J. J. Hybrid phase ligation for efficient synthesis of histone proteins. Org. Biomol. Chem. 2016, 14, 2603-2607.

7. (a) Merrifield, R. B. Solid Phase Peptide Synthesis. I. The Synthesis of a Tetrapeptide. J. Am. Chem. Soc. 1963, 85, 2149-2154. (b) Behrendt, R.; White, P.; Offer, J. Advances in Fmoc solid-phase peptide synthesis. J. Pept. Sci. 2016, 22, 4-27.

8. Dawson, P. E.; Muir, T. W.; Clark-Lewis, I.; Kent, S. B. Synthesis of proteins by native chemical ligation. Science 1994, 266, 776-779.

9. (a) Zuo, C.; Zhang, B.; Yan, B.: Zheng, J. S. One-pot multi-segment condensation strategies for chemical protein synthesis. Org. Biomol. Chem. 2019, 17, 727-744. (b) Nakatsu, K.; Hayashi, G.; Okamoto, A. Curr. Opin. Chem. Biol. 2020, 58, 10-19.

10. (a) Chalker, J. M.; Wood, C. S. C.; Davis, B. G. A Convenient Catalyst for Aqueous and Protein Suzuki-Miyaura Cross-Coupling. J. Am. Chem. Soc. 2009, 131, 16346-16347. (b) Tilley, S. D.; Francis, M. B. Tyrosine-Selective Protein Alkylation Using $\pi$-Allylpalladium Complexes. J. Am. Chem. Soc. 2006, 128, 1080-1081. (c) Vinogradova1, E. V.; Zhang, C.; Spokoyny, A. M.; Pentelute, B. L.; Buchwald, S. L. Organometallic palladium reagents for cysteine bioconjugation. Nature 2015, 526, 687-691. (d) Kwan, T. T.-L.; Boutureira, Omar.; Frye, E. C.; Walsh, S. J.; Gupta M. K.; Wallace, S.: Wu, Y.; Zhang, F.; Sore, H. F.; Galloway, W. R. J. D.; Chin, J. W.; Welch, M.; Bernardes, G. J. L.; Spring, D. R. Protein modification via alkyne hydrosilylation using a substoichiometric amount of ruthenium(II) catalyst. Chem. Sci. 2017, 8, 3871-3878.

11. (a) Latocheski, E.; Dal Forno, G. M.; Ferreira, T. M.; Oliveira, B. L.; Bernardes, G.; Domingos, J. B. Mechanistic insights into transition metal-mediated bioorthogonal uncaging reactions. Chem. Soc. Rev. 2020, 49, 7710-7729. (b) Li, J.; Yu, J.; Zhao, J.; Wang, J. Zheng, S.; Lin, S.; Chen, L.; Yang, M.; Jia, S.; Zhang, X.; Chen, P. R. Palladium-triggered deprotection chemistry for protein activation in living cells. Nat. Chem. 2014, 6, 352-361. (c) Stenton, B. J.; Oliveira, B. L.; Matos, M. J.; Sinatra, L.; Bernardes, G. A thioether-directed palladium-cleavable linker for targeted bioorthogonal drug decaging. Chem. Sci. 2018, 9, 4185-4189. (d) Brabham, R. L.; Spears, R. J.; Walton, J.; Tyagi, S.; Lemkeb, E. A.; Fascione, M. A. Palladiumunleashed proteins: gentle aldehyde decaging for site-selective protein modification. Chem. Commun. 2018, 54, 1501-1504. (e) Jbara, M.; Eid, E.; Brik, A. Gold(I)-Mediated Decaging or Cleavage of Propargylated Peptide Bond in Aqueous Conditions for Protein Synthesis and Manipulation. J. Am. Chem. Soc. 2020, 142, 8203-8210.

12. (a) Jbara, M.; Maity, S. K.; Brik, A. Palladium in the Chemical Synthesis and Modification of Proteins. Angew. Chem., Int. Ed.
2017, 56, 10644-10655. (b) Maity, S. K.; Jbara, M.; Mann, G.; Kamnesky, G.; Brik, A. Total chemical synthesis of histones and their analogs, assisted by native chemical ligation and palladium complexes. Nat. Protoc. 2017, 12, 2293-2322. (c) Jbara, M.; Maity, S. K.; Seenaiah, M.; Brik, A. Palladium Mediated Rapid Deprotection of N-Terminal Cysteine under Native Chemical Ligation Conditions for the Efficient Preparation of Synthetically Challenging Proteins. J. Am. Chem. Soc. 2016, 138, 5069-5075. (d) Maity, S. K.; Jbara, M.; Laps, S.; Brik, A. Efficient Palladium-Assisted One-Pot Deprotection of (Acetamidomethyl)Cysteine Following Native Chemical Ligation and/or Desulfurization to Expedite Chemical Protein Synthesis. Angew. Chem. Int. Ed. 2016, 55, 8108-8112. (e) Maity, S. K.; Mann, G.; Jbara, M.; Laps, S.; Kamnesky, G.; Brik, A. Palladium-Assisted Removal of a Solubilizing Tag from a Cys Side Chain To Facilitate Peptide and Protein Synthesis. Org. Lett. 2016, 18, 3026-3029. (f) Jbara, M.; Laps, S.; Maity, S. K.; Brik, A. Palladium-Assisted Cleavage of Peptides and Proteins Containing Backbone with Thiazolidine Linkage. Chem. Eur. J. 2016, 22, 14851-14855. (g) Laps, S.; Sun, H.; Kamnesky, G.; Brik, A. Palladium-Mediated Direct Disulfide Bond Formation in Proteins Containing S-Acetamidomethyl-cysteine under Aqueous Conditions. Angew. Chem. Int. Ed. 2019, 58, 5729-5733. (h) Jbara, M.; Maity, S. K.; Brik, A. Examining Several Strategies for the Chemical Synthesis of Phosphorylated Histone H3 Reveals the Effectiveness of the Convergent Approach. Eur. J. Org. Chem. 2020, 3128-3132. (i) Vamisetti, G. B.; Satish, G.; Sulkshane, P.; Mann, G.; Glickman, M. H.; Brik, A. On-Demand Detachment of Succinimides on Cysteine to Facilitate (Semi)Synthesis of Challenging Proteins. J. Am. Chem. Soc. 2020, DOI: 10.1021/jacs.0c07663.

13. Kamo, N.; Hayashi, G.; Okamoto, A. Triple Function of 4Mercaptophenylacetic Acid Promotes One-Pot Multiple Peptide Ligation. Angew. Chem. Int. Ed. 2018, 57, 16533-16537.

14. (a) Tamás, M. J., Sharma, S. K., Ibstedt, S., Jacobson, T., \& Christen, P. Biomolecules. 2014, 4, 252-267. (b) Poulson, B. G.; Szczepski, K.; Lachowicz, J. I.; Jaremko, L.; Emwas, A. H.; Jaremko, M. Aggregation of biologically important peptides and proteins: inhibition or acceleration depending on protein and metal ion concentrations. RSC Adv. 2020, 10, 215-227.

15. Völker T.; Dempwolff, F.; Graumann, P. L.; Meggers, E. Progress towards Bioorthogonal Catalysis with Organometallic Compounds. Angew. Chem. Int. Ed. 2014, 53, 10536-10540.

16. Peral, D.; Herrera, D.; Real, J.; Flor, T.; Bayón, J. C. Strong $\pi$ acceptor sulfonated phosphines in biphasic rhodium-catalyzed hydroformylation of polar alkenes. Catal. Sci. Technol. 2016, 6, 800-808.

17. Genin, E.; Amengual, R.; Michelet, V.; Savignac, M.; Jutand, A.; Neuville, L.; Genêt, J. P. A Novel Water-Soluble $m$-TPPTC Ligand: Steric and Electronic Features - Recent Developments in Pd- and Rh-Catalyzed C-C Bond Formations. Adv. Synth. Catal. 2004, 346, 1733-1741.

18. Snelders, D. J. M.; van Koten, G.; Klein Gebbink, R. J. M. Steric, Electronic, and Secondary Effects on the Coordination Chemistry of Ionic Phosphine Ligands and the Catalytic Behavior of Their Metal Complexes. Chem. Eur. J. 2011, 17, 42-57.

19. Ohana, R. F.; Levin, S.; Wood, M. G.; Zimmerman, K.; Dart, M. L.; Schwinn, M. K.; Kirkland, T. A.; Hurst R.; Uyeda, H. T.; Encell, L. P.; Wood, K. V. Improved Deconvolution of Protein Targets for Bioactive Compounds Using a Palladium Cleavable Chloroalkane Capture Tag. ACS Chem. Biol. 2016, 11, 2608-2617.

20. Koning, B.; Meetsma, A.; Kellogg, R. M. Chiral Nonracemic Pyridine Thiols and Thioethers Applied in Palladium-Catalyzed Allylic Substitution. An Example of Near-Perfect Enantioselection, J. Org. Chem. 1998, 63, 5533-5540.

21. Kolpin, A.; Jones, G.; Jones, Simon.; Zheng, W.; Cookson, J.; York, A. P. E.; Collier, P. J.; Tsang, S. C. E. Quantitative Differences in Sulfur Poisoning Phenomena over Ruthenium and Palladium: An Attempt To Deconvolute Geometric and Electronic Poisoning Effects Using Model Catalysts. ACS Catal. 2017, 7, 592-605. 
22. Sundararaju, B.; Achard, M.; Bruneau, C. Transition metal catalyzed nucleophilic allylic substitution: activation of allylic alcohols via $\pi$-allylic species. Chem. Soc. Rev. 2012, 41, 4467-4483.

23. Kondo, T.; Morisaki, Y.; Uenoyama, S.; Wada, K.; Mitsudo, T. First Ruthenium-Catalyzed Allylation of Thiols Enables the General Synthesis of Allylic Sulfides. J. Am. Chem. Soc. 1999, 121 8657-8658.

24. Tanaka, S.; Pradhan, P. K.; Maegawa, Y.; Kitamura, M. Highly efficient catalytic dehydrative S-allylation of thiols and thioic Sacids. Chem. Commun. 2010, 46, 3996-3998.

25. Mbaye, M. D.; Demerseman, B.; Renaud, J. L.; Toupet, L.; Bruneau, C. $\left[\mathrm{Cp}^{*}\left(\eta_{2}\right.\right.$-bipy)(MeCN)Ru $\left.\mathrm{Ru}^{\mathrm{II}}\right]\left[\mathrm{PF}_{6}\right]$ Catalysts for Regioselective Allylic Substitution and Characterization of Dicationic $\left[\mathrm{Cp}^{*}\left(\eta_{2}\right.\right.$-bipy $)-\left(\eta_{3}\right.$-allyl $\left.) \mathrm{Ru}^{\mathrm{IV}}\right]\left[\mathrm{PF}_{6}\right]_{2}$ Intermediates. Angew. Chem. Int. Ed. 2003, 42, 5066-5068.

26. Sundararaju, B.; Achard, M.; Demerseman, B.; Toupet, L.; Sharma G. V. M.; Bruneau, C. Ruthenium(IV) Complexes Featuring P,O-Chelating Ligands: Regioselective Substitution Directly from Allylic Alcohols. Angew. Chem. Int. Ed. 2010, 49, 2782-2785.

27. Johnson, E. C. B.; Kent, S. B. H. J. Am. Chem. Soc. 2006, 128, 6640-6646.

28. Similar binuclear $\mathrm{Ru}$ complexes with bridging thiolate anions were reported. (a) Zaitsev, A. B.; Caldwell, H. F.; Pregosin, P. S.; Veiros, L. F. Fast Ruthenium-Catalysed Allylation of Thiols by Using Allyl Alcohols as Substrates. Chem. Eur. J. 2009, 15, 64686477. (b) Mashima, K.; Kaneyoshi, H.; Kaneko, S.; Mikami, A.; Tani, K.; Nakamura, A. Chemistry of Coordinatively Unsaturated Bis(thiolato)ruthenium(II) Complexes ( $\eta^{6}$-arene) $\mathrm{Ru}(\mathrm{SAr})_{2}$ [SAr = 2,6-Dimethylbenzenethiolate, 2,4,6-Triisopropylbenzenethiolate; $(\mathrm{SAr})_{2}=1,2$-Benzenedithiolate; Arene = Benzene, $p$-Cymene, Hexamethylbenzene]. Organometallics 1997, 16, 1016-1025.

29. Harshman, S. W.; Young, N. L.; Parthun, M. R.; Freitas, M. A. H1 histones: current perspectives and challenges. Nucleic Acids Res. 2013, 41, 9593-9609.

30. Hergeth, S. P.; Schneider, R. The H1 linker histones: multifunctional proteins beyond the nucleosomal core particle. EMBO Rep. 2015, 16, 1439-1453.

31. Flanagan, T. W.; Brown, D. T. Molecular dynamics of histone H1. Biochim. Biophys. Acta Gene Regul. Mech. 2016, 1859, 468-475. 32. Izzo, A.; Schneider, R. The role of linker histone H1 modifications in the regulation of gene expression and chromatin dynamics. Biochim. Biophys. Acta Gene Regul. Mech. 2016, 1859, 486-495. 33. Fyodorov, D. V.; Zhou, B. R.; Skoultchi, A. I.; Bai, Y. Emerging roles of linker histones in regulating chromatin structure and function. Nat. Rev. Mol. Cell Biol. 2018, 19, 192-206.

34 . Recently, Hong et al. reported the chemical synthesis of linker histone H1.2 through sequential ligations on the solid phase. Hong, Z. Z.; Yu, R. R.; Zhang, X.; Webb, A. M.; Burge, N. L.; Poirier, M. G.; Ottesen, J. J. Convergent Hybrid Phase Ligation Strategy for Efficient Total Synthesis of Large Proteins Demonstrated for 212residue Linker Histone H1.2. bioRxiv. 2019, DOI: 10.1101/661744 35. Wan, Q. Danishefsky, S. J. Free-Radical-Based, Specific Desulfurization of Cysteine: A Powerful Advance in the Synthesis of Polypeptides and Glycopolypeptides. Angew. Chem. Int. Ed. 2007, 46, 9248-9252.

36. Christophorou, M. A.; Castelo-Branco, G.; Halley-Stott, R. P.; Oliveira, C. S.; Loos, R.; Radzisheuskaya, A.; Mowen, K. A.; Bertone, P.; Silva, J. C. R.; Zernicka-Goetz, M.; Nielsen, M. L.; Gurdon, J. B.; Kouzarides, Tony. Citrullination regulates pluripotency and histone H1 binding to chromatin. Nature 2014, 507, 104-108.

37. Sarg, B.; Helliger, W.; Talasz, H.; Förg, B.; Lindner, H. H. Histone H1 Phosphorylation Occurs Site-specifically during Interphase and Mitosis. Identification of a Novel Phosphorylation Site on Histone H1. J. Biol. Chem. 2006, 281, 6573-6580.

38. Shintomi, K.; Iwabuchi, M.; Saeki, H.; Ura, K.; Kishimoto, T.; Ohsumi, K. Nucleosome assembly protein-1 is a linker histone chaperone in Xenopus eggs. Proc. Natl. Acad. Sci. USA. 2005, 102, 8210-8215.
39. Bednar, J.; Garcia-Saez, I.; Boopathi, R.; Cutter, A. R., Papai, G.; Reymer, A.; Syed, S. H.; Lone, I. N.; Tonchev, O.; Crucifix, C.; Menoni, H.; Papin, C.; Skoufias, D. A.; Kurumizaka, H.; Lavery, R.; Hamiche, A.; Hayes, J. J.; Schultz, P.; Angelov, D.; Petosa, C.; Dimitrov, S. Structure and Dynamics of a 197 bp Nucleosome in Complex with Linker Histone H1. Mol. Cell. 2017, 66, 384-397.

40. Maison, C.; Almouzni, G. HP1 and the dynamics of heterochromatin maintenance. Nat. Rev. Mol. Cell Biol. 2004, 5, 296-305. 41. Canzio, D.; Larson, A.; Narlikar, G. J. Mechanisms of functional promiscuity by HP1 proteins. Trends Cell Biol. 2014, 24, 377-386. 42. Nishibuchi, G.; Nakayama, J. Biochemical and structural properties of heterochromatin protein 1: understanding its role in chromatin assembly. J. Biochem. 2014, 156, 11-20.

43. Kumar, A.; Kono, H. Heterochromatin protein 1 (HP1): interactions with itself and chromatin components. Biophys. Rev. 2020, $12,387-400$

44. Becker, J. S.; Nicetto, D.; Zaret, K. S. H3K9me3-Dependent Heterochromatin: Barrier to Cell Fate Changes. Trends Genet. 2016, 32, 29-41.

45. Kanga, J.; Chaudharya, J.; Donga, H.; Kima, S.; Brautigamb, C. A.; $\mathrm{Yu}, \mathrm{H}$. Mitotic centromeric targeting of HP1 and its binding to Sgo1 are dispensable for sister-chromatid cohesion in human cells. Mol. Biol. Cell. 2011, 22, 1181-1190.

46. Machida, S.; Takizawa, Y.; Ishimaru, M.; Sugita, Y.; Sekine, S.; Nakayama, J.; Wolf, M.; Kurumizaka H. Structural Basis of Heterochromatin Formation by Human HP1. Mol. Cell. 2018, 69, 385397.

47. LeRoy, G.; Weston, J. T.; Zee, B. M.; Young, N. L. Heterochromatin Protein 1 Is Extensively Decorated with Histone Code-like Post-translational Modifications. Mol. Cell. Proteom. 2009, 8, $2432-2442$.

48. (a) Kamo, N.; Hayashi, G.; Okamoto, A. Efficient peptide ligation between allyl-protected Asp and Cys followed by palladiummediated deprotection. Chem. Commun. 2018, 54, 4337-4340. (b) Jbara, M.; Eid, E.; Brik, A. Palladium mediated deallylation in fully aqueous conditions for native chemical ligation at aspartic and glutamic acid sites. Org. Biomol. Chem. 2018, 16, 4061-4064.

49. (a) Villain, M.; Gaertner, H.; Botti, P. Eur. J. Org. Chem. 2003, 3267-3272. (b) Dang, B.; Kubota, T.; Mandal, K.; Bezanilla, F.; Kent, S. B. H. J. Am. Chem. Soc. 2013, 135, 11911-11919. (c) BlancoCanosa, J. B.; Nardone, B.; Albericio, F.; Dawson, P. E. J. Am. Chem. Soc. 2015, 137, 7197-7209.

50. Flood, D. T.; Hintzen, J. C. J.; Bird, M. J.; Cistrone, P. A.; Chen, J. S.; Dawson, P. E. Leveraging the Knorr Pyrazole Synthesis for the Facile Generation of Thioester Surrogates for use in Native Chemical Ligation. Angew. Chem. Int. Ed. 2018, 57, 11634-11639.

51. (a) Durek, T.; Torbeev, V. Y.; Kent, S. B. H. Convergent chemical synthesis and high-resolution $\mathrm{x}$-ray structure of human lysozyme. Proc. Natl. Acad. Sci. USA. 2007, 104, 4846-4851. (b) Murakami, M.; Kiuchi, T.; Nishihara, M.; Tezuka K.; Okamoto, R.; Izumi, M.; Kajihara, Y. Chemical synthesis of erythropoietin glycoforms for insights into the relationship between glycosylation pattern and bioactivity. Sci. Adv. 2016, 2, e1500678.

52. Hiragami-Hamada, K.; Shinmyozu, K.; Hamada, D.; Tatsu, Y.; Uegaki, K.; Fujiwara, S.; Nakayama, J. N-Terminal Phosphorylation of HP1 $\alpha$ Promotes Its Chromatin Binding. Mol Cell Biol. 2011, 31, 1186-1200.

53. Nishibuchi, G.; Machida, S.; Osakabe, A.; Murakoshi, H.; Hiragami-Hamada, K.; Nakagawa, R.; Fischle, W.; Nishimura, Y.; Kurumizaka, H.; Tagami, H.; Nakayama, J. N-terminal phosphorylation of HP1 $\alpha$ increases its nucleosome-binding specificity. Nucleic Acids Res. 2014, 42, 12498-12511.

54. Minc, E.; Allory, Y.; Worman, H. J.; Courvalin, J.-C.; Buendia, B. Localization and phosphorylation of HP1 proteins during the cell cycle in mammalian cells. Chromosoma. 1999, 108, 220-234.

55. Chakraborty, A.; Prasanth, K. V.; Prasanth, S. G. Dynamic phosphorylation of HP1 $\alpha$ regulates mitotic progression in human cells. Nat. Commun. 2014, 5, 3445. 
56. Nishibuchi, G.; Machida, S.; Nakagawa, R.; Yoshimura, Y.; Hiragami-Hamada, K.; Abe, Y.; Kurumizaka, H.; Tagami, H.; Nakayama, J. Mitotic phosphorylation of HP1 $\alpha$ regulates its cell cycledependent chromatin binding. J. Biochem. 2019, 165, 433-446.

57. Chen, S.; Wang, C.; Sun, L. Wang, D.-L.; Chen, L.; Huang, Z.; Yang, Q.; Gao, J.; Yang, X.-B.; Chang, J.-F.; Chen, P.; Lan, L.; Mao, Z.; Sun, F.L. RAD6 Promotes Homologous Recombination Repair by Activating the Autophagy-Mediated Degradation of Heterochromatin Protein HP1. Mol Cell Biol. 2015, 35, 406-416.

58. Tang, S.; Liang, L. J.; Si, Y. Y.; Gao, S.; Wang, J. X.; Liang, J. Mei, Z. Zheng, J. S.; Liu, L. Practical Chemical Synthesis of Atypical Ubiquitin Chains by Using an Isopeptide-Linked Ub Isomer. Angew. Chem. Int. Ed. 2017, 56, 13333-13337.

59. Hayakawa, T.; Haraguchi, T.; Masumoto, H.; Hiraoka, Y. Cell cycle behavior of human HP1 subtypes: distinct molecular domains of HP1 are required for their centromeric localization during interphase and metaphase. J. Cell Sci. 2003, 116, 3327-3338. 